\title{
Mediterranean nekton traits: Distribution, relationships and significance for marine ecology monitoring and management
}

\author{
Evangelos Tzanatos ${ }^{\text {Corresp., } 1}{ }^{1}$, Catherine Moukas ${ }^{1}$, Martha Koutsidi ${ }^{1}$ \\ ${ }^{1}$ Department of Biology, University of Patras, Patras, Greece \\ Corresponding Author: Evangelos Tzanatos \\ Email address: tzanatos@upatras.gr
}

Biological traits are increasingly used in order to study aspects of ecology as they are related to the organisms' fitness. Here we analyze a dataset of 23 traits regarding the life cycle, distribution, ecology and behavior of 235 nektonic species of the Mediterranean Sea in order to evaluate the distribution of traits, identify rare ones, detect relationships between trait pairs and identify species functional groups. Trait relationships were tested using correlation and non-linear regression for continuous traits, parametric and nonparametric inference tests for pairs of continuous-categorical traits and cooccurrence testing for categorical traits. The findings have significant implications concerning the potential effects of climate change (e.g. through the relationships of the trait of optimal temperature), fisheries or habitat loss (from the relationships of traits related to tolerance ranges). Furthermore, some unexpected relationships are documented, like the inversely proportional relationship between longevity and age at maturity as a percentage of life span. Associations between functional traits show affinities derived from phylogenetic constraints or life strategies, however relationships among functional and ecological traits can indicate the potential environmental filtering that acts on functional traits. In total, 18 functional groups were identified by Hill-Smith ordination and hierarchical clustering and were characterized by their dominant traits. For the assessment of the results, we first evaluate the importance of each trait at the level of population, community, ecosystem and landscape and then propose the traits that should be monitored for the regulation and resilience of ecosystem functioning and the management of the marine ecosystems. 


\section{Mediterranean nekton traits: Distribution,}

3 relationships and significance for marine ecology

4 monitoring and management

5

6

7 Evangelos Tzanatos, Catherine Moukas, Martha Koutsidi

8

9

10

11

12

13

14

15

16

17

\section{Introduction}

Department of Biology, University of Patras, Rio, Patras, Greece

Corresponding Author:

Evangelos Tzanatos

Email address: tzanatos@upatras.gr

\section{Abstract}

Department of Biology, University of Patras, Rio, Patras, GR26504, Greece

Biological traits are increasingly used in order to study aspects of ecology as they are related to the organisms' fitness. Here we analyze a dataset of 23 traits regarding the life cycle, distribution, ecology and behavior of 235 nektonic species of the Mediterranean Sea in order to evaluate the distribution of traits, identify rare ones, detect relationships between trait pairs and identify species functional groups. Trait relationships were tested using correlation and nonlinear regression for continuous traits, parametric and non-parametric inference tests for pairs of continuous-categorical traits and cooccurrence testing for categorical traits. The findings have significant implications concerning the potential effects of climate change (e.g. through the relationships of the trait of optimal temperature), fisheries or habitat loss (from the relationships of traits related to tolerance ranges). Furthermore, some unexpected relationships are documented, like the inversely proportional relationship between longevity and age at maturity as a percentage of life span. Associations between functional traits show affinities derived from phylogenetic constraints or life strategies, however relationships among functional and ecological traits can indicate the potential environmental filtering that acts on functional traits. In total, 18 functional groups were identified by Hill-Smith ordination and hierarchical clustering and were characterized by their dominant traits. For the assessment of the results, we first evaluate the importance of each trait at the level of population, community, ecosystem and landscape and then propose the traits that should be monitored for the regulation and resilience of ecosystem functioning and the management of the marine ecosystems.

Today, the characteristics of organisms, usually referred to as traits, are increasingly used in order to study aspects of biology and ecology as they are related to the organisms' ability to 
40

41

42

43

44

45

46

47

48

49

50

51

52

53

54

55

56

57

58

59

60

61

62

63

64

65

66

67

68

69

70

71

72

73

74

75

76

77

78

79

80

81

82

83

84

survive, grow and produce offspring, i.e. to influence their fitness (Violle et al., 2007). The socalled traits-based approaches, comprise an arsenal of methods that use traits instead of taxonomic information to characterize ecosystems, providing various advantages like alternative ways to study biological communities and their functioning (Bellwood, Hoey \& Choat, 2003; Bremner, 2008; Pecuchet et al., 2017, 2018). Furthermore, they can be used to elucidate the effects of environmental or anthropogenic stressors on ecosystem functioning (Frelat et al., 2018; McLean, Mouillot \& Auber, 2018).

However, the study of biological traits is not novel in marine biology. Traits have long been studied in order to determine relationships between aspects of an organisms' physiology or ecology. Additionally, evolutionary processes have provided specific combinations of characteristics to organisms; hence the traits appearing in any given species are not random (e.g. Winemiller \& Rose, 1992; Charnov, 1993). It has been demonstrated that traits are not only related, as there are various relationships among them, but also there are trade-offs between them because of physiological constraints (Litchman et al. 2013). As the energy captured must be used to achieve maintenance, growth and reproduction of the organism, the allocation of energy between these in time (spanning aspects ranging from physiology to ecology) shapes the major aspects of the species' life histories. Trait combination into life histories serves functions like survival, growth, sexual maturation and reproduction at the organismal level (Beverton \& Holt, 1959; Beverton, 1992) shaping fitness that can act at the level of populations and, ultimately, communities. However, the relationships between traits can be important, not only for understanding how evolution has shaped life into form and function (Charnov, Gislason \& Pope, 2013), but also in order to assess the potential effects of environmental factors. Even more so as, apart from environmental filtering (Bejarano et al., 2017), anthropogenic stressors like fisheries can favour the selection of specific traits (e.g. de Juan et al. 2007) and thus indirectly alter future community trait composition, possibly modifying the functioning of communities or the ecosystem. As a result, there is a probability that the selection of specific traits may lead to changes in the frequencies of others that are associated with them as a side effect. This supposition gives novel importance to the study of relationships between traits. Furthermore, the study of trait frequencies and the identification of rare traits may indicate keystone species for ecosystem functioning (Violle et al., 2017).

In order to comprehend the functional aspect of traits and the implications of their relationships it is important to document their significance not only for shaping the life history of an organism at the level of the individual. Highlighting the importance of traits at the population scale comes easily, as traits are related to the adaptations of the species to its environment aiming to maximize fitness at the individual and population level (Violle et al., 2007). Various works have examined the significance of traits for the population/species possessing them (e.g. Tornroos \& Bonsdorff, 2012; Costello et al., 2015; Henseler et al., 2019). Villeger et al. (2017) expand the relation of functioning at the population level to ecosystem processes and services. However, an overall evaluation of the importance or the implications of biological traits should be carried out at levels beyond that of the population, especially for nekton, where a multitude of species are under exploitation and inter-specific interactions have raised important challenges. Thus, a brief presentation of the significance and implications of nekton traits at various ecological levels, i.e. (a) that of the population, (b) interspecific relationships and communities, (c) overall ecosystem functioning and even (d) relevance for anthropogenic effects like fisheries and climate change is presented in Table 1. 
85

86

87

88

89

90

91

92

93

94

95

96

97

98

99

100

101

102

103

104

105

106

107

108

109

110

111

112

113

114

115

116

117

118

119

120

121

122

123

124

125

126

127

128

While the term "trait" generally refers to morphological, physiological or phenological features that are measurable at the individual level without reference to the environment, Violle et al. (2007) define as functional traits the characteristics that may affect survival, growth, or reproduction and thus indirectly impact fitness. Beauchard et al. (2017) determine as ecological traits characteristics related to environmental preferences (like optimal temperature or depth). Often, analyses of trait patterns focus on functional traits (e.g. to determine how evolution has shaped life strategies), however the inclusion of data on ecological traits in the analyses can provide insights into how the environment may affect aspects of organismal fitness by associations with functional traits.

The investigation of patterns and relationships between traits are especially important for regions that host a high biodiversity like the Mediterranean Sea (Myers et al., 2000, Bianchi \& Morri, 2000). Furthermore, the Mediterranean has a long history of human presence and is today facing challenges due to stressors that are either novel or are acting at unprecedented levels (Lejeusne et al., 2010). Koutsidi et al. (2016) have already studied traits relationships and rarity; however, in that work traits had been assembled only for a limited number of species (mainly commercial species targeted or caught by fisheries). Additionally, in that work traits had been evaluated only as categorical variables (i.e. with each trait being described by trait categories). This may possibly have blurred the results in the case of quantitative traits like life span or size.

The aim of the present study is to use an extensive dataset of 23 traits assembled from the bibliography for 235 nektonic species of the Mediterranean Sea in order to: (a) determine whether there are rare or dominant traits by evaluating the distribution of traits, (b) detect whether there are undocumented relationships between pairs of biological traits by looking for patterns between functional traits, ecological traits or both, (c) identify functional groups and (d) evaluate selected rare traits with regard to climate change and to species' resilience to human impact.

\section{Materials \& Methods}

Information on 23 traits related to the life cycle, distribution, ecology and behaviour of 235 species of nekton (217 fish, 10 cephalopods, 8 crustaceans) occurring in the Mediterranean Sea was collected from the bibliography (Table 2). For species selection, an already existing dataset assembled and analyzed in the work of Koutsidi et al. (2016) was extended, using as criteria to: (a) cover the catches of the common commercial fishing gears as much as possible. Compared against the onboard sampling catch composition data, i.e. species both landed and discarded by fishermen, from the application of the European Union Data Collection Framework (EC 199/2008) in the eastern Ionian Sea (GFCM area: GSA20) in 2013-2014 the species accounted for over $98 \%$ of the catches in terms of biomass (both total catches and also catches by gear, which for some gears reached 100\%), (b) adequately depict the traits of the fisheries landings in a pan-Mediterranean scale. Compared to the FAO-GFCM landings dataset of 2015, after excluding general organismal categories (like "fishes" or "mollusks"), the dataset corresponded to $75 \%$ of the total landings (which naturally also include various benthic species like bivalves) by taxon, (c) include all the species found in highly diverse habitats: For this we included the inventory of species from Posidonia beds and coralligène formations, that comprise the two marine habitats with the highest biodiversity in the Mediterranean. Regarding coralligène

Peer) reviewing PDF | (2019:09:41011:1:1:NEW 20 Dec 2019) 
129 formations, information was obtained from the review article by Ballesteros (2006). As there was 130 no review on the nekton of Posidonia beds, we included the lists from five different publications 131 -that use different sampling techniques and come from different areas of the Mediterranean Sea: 132 Francour (1997); Guidetti (2000); Fernandez et al. (2005); Moranta et al. (2006); Kalogirou, et 133 al. (2010), (d) Incorporate species distributed in lagoons that are highly productive ecosystems 134 with brackish characteristics (Nikolaidou et al., 2010). Overall, we included 68 species from 135 Posidonia beds, 26 species from coralligène formations and 28 species from lagoons, (e) finally, 22 Lessepsian species (species invading the Mediterranean Sea through the Suez canal), as listed by the review of Corsini-Foka \& Economidis (2007), were also included. Even though some of these 235 species can be characterized as benthic (e.g. Octopus vulgaris, Nephrops norvegicus or fish species living in burrows/crevices) they were included in the dataset as they mainly interact with nekton and are not sessile.

Trait information is often found in printed sources (e.g. fish identification keys) and terms are not standardized. Thus, no systematic review could be performed. Instead, the information was collected from books, review articles or journal research articles by searching using the species name and adding the name of the trait or relevant terms (e.g. "life span" instead of "longevity", "reproduction" instead of "spawning period"). Regarding reference sources, we preferred to use information from peer-reviewed publications or books over grey literature. As the objective was to collect data on Mediterranean species, when there was a unique reference about a species it was used regardless of the source, however, if there was information coming from locations outside and inside the Mediterranean (e.g. from two different papers), preference was given to the latter. If there were multiple sources of information from different areas within the Mediterranean (e.g. from various papers), we chose the references from the central Mediterranean (Ionian Sea). Regarding habitats, again we preferred information coming from marine habitats (e.g. rather than brackish waters or lagoons) if a species is distributed in many habitat types. In the case of species that can be found over different substrates and we had different publications with variable trait values we tried to focus on the most common habitat.

The various traits comprise different types of variables: continuous (e.g. size or maximum lifespan), range (e.g. depth) and categorical (e.g. spawning habitat: pelagic or benthic). Concerning categorical traits, each species was assigned to one trait category/modality per trait. The definition of these 23 traits and their modalities is provided in Supplementary Table $\mathrm{S} 1$. The information on traits as continuous variables and the information on traits categories per species as well as the bibliographic reference for the documentation of each trait per species can be found at:

https://figshare.com/articles/Koutsidi_Moukas_Tzanatos_23 biological_traits_of_235_species/1 $\underline{1347406}$

For the detection of patterns in their distribution, the range type traits (fecundity, optimal depth, optimal temperature, trophic level) were expressed as such, while for statistical tests and the detection of relationships between trait pairs they were used as the average between the minimum and the maximum (thus used as continuous type traits). Continuous and range-type traits were investigated for outlier detection using the Grubbs test (Grubbs, 1950). As this test is parametric, it was performed after the log-transformation of the traits: longevity and maximum length, while age at maturity was transformed using the square root to achieve normality. As average fecundity and average depth could not be described by a normal distribution with any possible transformation the Grubbs test was not used on these variables. Regarding the 
174 identification of rare traits, the distribution of trait values (for continuous variable-type trait) or

175 the frequencies of trait categories (for categorical variable-type trait) allowed the identification of 176 rare traits as these shared by less than $5 \%$ of species.

To identify potential relationships the continuous traits longevity, fecundity, maximum length and depth were transformed using the natural logarithm. Each of the total of 23 traits was examined for the existence of a potential relationship with all other ones, depending on their types. Regarding pairs of continuous traits, Pearson correlation between all pairs of continuous traits was used. As carrying out a test for multiple hypotheses increases the probability of a rare event, the likelihood of incorrectly rejecting the null hypothesis (Type I error) increases; hence in the results the Bonferroni correction was incorporated. Correlation has the advantage of investigating relationships without assuming causality, however it can only detect linear relationships. In cases where the residuals indicated a non-linear pattern, a polynomial regression was additionally used to investigate the existence of non-linear relationships and, in cases of better fit, these relationships are presented instead.

For the detection of relationships between continuous and categorical traits, the t-test or Analysis of Variance (ANOVA) was used, depending on the number of categories of the categorical trait. As these tests are parametric, the Shapiro-Wilk's test was used to test for normality. Fischer's exact test (for traits including only two trait categories) or Levene's test (for traits with more than two trait categories) were used to examine the homogeneity of variances. Regarding normality, only longevity and maximum length (their logarithm) were found to follow a normal distribution. As in general, both ANOVA and t-test are considered as robust inferential tests (Zar 1999), if the tests for homogeneity of variance did not reject the null hypothesis the parametric tests were used. In the cases where the parametric prerequisites were not fulfilled, the Mann-Whitney or Kruskal-Wallis tests were used instead (Zar, 1999). Similarly, we incorporated the Bonferroni correction here.

To detect relationships between categorical traits, we followed the approach by Koutsidi, et al. (2016) that had been used for a smaller number of traits (21) and species (86). This approach investigates pairwise patterns of traits co-occurrence and compares these cooccurrences to the number of randomly expected ones, characterizing them thus as positive (the pair of traits tends to co-occur more than expected by the product of their independent frequencies), negative (the pair of traits tends to co-occur less than expected by the product of their independent frequencies) or random co-occurrences. For this analysis we used the library "co-occur" (Griffith, Veech \& Marsh, 2016) in R-language (R Core Team 2019).

For the identification of species functional groups, first we carried out a Hill-Smith ordination (Hill \& Smith 1976) of the species for which we had a complete 23 trait dataset. This type of analysis can handle both continuous (range-type traits were analyzed as continuous variables using their average) and categorical variables concurrently. In order to provide equal weights to all traits we expressed all continuous-type traits as percentages of their maximum value. From the results of the Hill-Smith ordination we analyzed the species coordinates on the 11 major axes derived (58\% of variance explained) by hierarchical clustering carried out using Ward's method, similar to Benedetti et al. $(2016,2018)$. For this analysis we used the library "ade4" in R (Dray \& Dufour 2007).

The groups identified by the above method, were then characterized by their traits. Regarding categorical traits: (a) we considered that if more than $90 \%$ of the species of a group share a specific modality of a certain trait then the entire group is characterized by this modality 
219 (as a major percentage of species possess it). Furthermore, (b) we highlighted modalities that 220 have particular importance for a group, i.e. (even if not shared by more than $90 \%$ of the species) 221 were found in a percentage that was more than $20 \%$ (arbitrarily defined) higher compared to that 222 modality percent frequency in the species pool. For continuous traits, we compared the averages 223 of the 18 functional groups through ANOVA (optimal temperature) or their medians through

224 Kruskal-Wallis (all other traits, as the parametric prerequisites were not fulfilled) and, in case of 225 statistical significance, indicate the groups with highest/lowest averages or medians in the 226 functional group characterization.

227

228

229

230

231

232

233

234

235

236

237

238

239

240

241

242

243

244

245

246

247

248

249

250

251

252

253

254

255

256

257

258

259

260

261

262

263

The significance level $\alpha=0.05$ was used for all inferential tests, subsequently incorporating the Bonferroni correction as stated above.

\section{Results}

Trait frequencies and distributions allowed the identification of dominant and rare traits in the 235 species examined. Regarding continuous traits, $89.6 \%$ of the species examined were found to have a maximum life span of up to 25 years (minimum: 1.1 years, maximum: 118.0 years, average: 14.4 years, median: 9 years), but life cycles can reach up to $\sim 120$ years with the rare high longevity frequency classes shared in most cases by only a few species (Figure 1A). Concerning age at maturity as a percentage of lifespan (minimum: 2.0\%, maximum: 75.0\%, average: $25.2 \%$, median: $21.8 \%$ ), both early and late age at maturity come as outliers with low frequencies (Figure 1B). Finally, regarding size (minimum: $5.0 \mathrm{~cm}$, maximum: $800 \mathrm{~cm}$, average: $63.7 \mathrm{~cm}$, median: $37.4 \mathrm{~cm}$ ), nekton species with a maximum length over $\sim 80 \mathrm{~cm}$ were uncommon ( $\sim 78 \%$ of species examined may reach below this size), while nekton reaching $2-8 \mathrm{~m}$ were scarce. Slightly over 5\% were the number of nekton species with a maximum size below 10 $\mathrm{cm}$ (Figure 1C). No outliers were found in the log-transformed longevity (Grubbs test, $\mathrm{G}=2.82$, $\mathrm{p}=0.91$ ) and maximum length data (Grubbs test, $\mathrm{G}=3.25, \mathrm{p}=0.23$ ) or in the square root age at maturity (Grubbs test, $\mathrm{G}=3.44$, $\mathrm{p}=0.10$ ).

For range type traits (Figure 1D-G), fecundity showed a distribution where the extreme values (low and high fecundities) are represented by only a few species, whereas the majority of species demonstrate very similar fecundity ranges (also indicated by the S-shaped curve in the figure). Especially the values of low fecundity are mostly associated with Chondrichthyes (the 20 species with the lowest fecundity values are all cartilaginous fish). The highest values of fecundity were obtained by a heterogeneous group of species (Thunnus thynnus, Labrus merula, Psetta maxima, Scophthalmus rhombus, Polyprion americanus). Distribution across depth is relatively continuous with many species being distributed in shallow depths (40 species with an average depth shallower than $20 \mathrm{~m}$ and 86 above $50 \mathrm{~m}$ ). Only a few species were found to be distributed in deep habitats (only 17 had an average depth deeper than $500 \mathrm{~m}$, but the case is that deep-living nekton generally includes species whose traits are relatively unknown and, as a result, were generally not included in the dataset of the 235 species examined here). The distribution of trophic level indicated the rarity of low (reaching up to trophic level 3) trophic level species among the nekton, while the distribution of optimal temperatures did not indicate important outliers. The Grubbs test indicated no outliers regarding average trophic level (Grubbs test, $\mathrm{G}=3.14, \mathrm{p}=0.34$ ) and optimal temperature (Grubbs test, $\mathrm{G}=2.15, \mathrm{p}=0.99$ ).

Regarding categorical traits (Figure 2), gonochorism (86\%), subtropical distribution (64\%), summer spawning (61\%), free exposure type (67\%), benthopelagic habitat use (63\%), grazing feeding type $(60 \%)$, eurythermal temperature range $(66 \%)$, stenohaline salinity range

Peer] reviewing PDF | (2019:09:41011:1:1:NEW 20 Dec 2019) 
$264(61 \%)$ and solitary behavior (57\%) were dominant trait categories among the species examined. 265 Flat (9\%) and long body shape (7\%), tropical (9\%) and cosmopolitan geographic distribution 266 (3\%), autumn (3\%), winter (7\%) and all year spawning (6\%), hard substrate seabed type (9\%),

267

268

269

270

271

272

273

274

275

276

277

278

279

280

281

282

283

284

285

286

287

288

289

290

291

292

293

294

295

296

297

298

299

300

301

302

303

304

305

306

307

308

309 ambusher mobility (6\%), ambushing predation feeding behaviour (7\%) and herbivorous $(2 \%)$ and zooplankton diet (9\%) were found to be shared by below $10 \%$ of the total species.

The relationships between continuous traits indicated eight statistically significant correlations, incorporating the Bonferroni correction (Table 3, Figure 3). Longevity had most correlations, with three positive ones (long-living organisms are larger, have high trophic level and dwell deeper) and one negative (long-living organisms have lower age at maturity -as a percentage of life span). Fecundity was found to increase with optimal temperature (Figure 3J), while maximum length increased with both trophic level and depth (Figure 3B, E). Depth and trophic level were also positively correlated (Figure 3H). Finally, in three cases, non-linear relationships provided better residual fit than linear ones (Figure 3C, F, I): fecundity was higher in species of low and high longevity $\left(\mathrm{R}^{2}=0.286, \mathrm{p}<0.001\right)$, fecundity had the highest values in intermediate depths $\left(\mathrm{R}^{2}=0.055, \mathrm{p}=0.004\right)$ and optimal temperature was higher in species of intermediate depths $\left(\mathrm{R}^{2}=0.046, \mathrm{p}=0.008\right)$, in the last two cases the correlation model explaining a low percentage of variance.

The relationships between continuous and categorical traits indicated 20 cases where there are significant statistical differences in the value of a continuous trait between the different modalities incorporating the Bonferroni correction (Table 4). The main findings are summarized in Table 5 (but see Supplementary Figure S1 for pairwise comparisons between trait categories). Longevity was highest in flat-shaped species, in ambushing and active predators, piscivorous species and pelagic spawners. Fecundity was higher in atractoid and pelagic species; however, if seabed type is also taken into account apart from open sea species hard substrate ones had higher values. Maximum length had significant variation across six categorical traits, with the most striking being the highest values in pelagics, pelagic spawners and non-migratory species. Regarding depth, eurybathic species and benthic spawners were found to occur deeper, herbivore diet/grazing behavior and euryhaline species were found shallower. The highest trophic level was naturally found in piscivorous species, ambushing predators (and mobility type) and eurybathic species. Optimal temperature was found to be higher in species of high and medium mobility, stenothermal species and species of tropical distribution.

The trait co-occurrence analysis documented $170(17.4 \%)$ positive, $183(18.8 \%)$ negative, and $622(63.8 \%)$ random modality associations (Figure 4). The modalities with the highest number of positive co-occurrences are associated with the pelagic (e.g. free exposure with 13 positive co-occurrences) or the benthic way of living (e.g. benthic spawning habitat with 14 positive co-occurrences, flat body shape and benthic habitat type with 13). The modalities with the highest number of negative co-occurrences are associated mostly with the pelagic way of living (atractoid body shape, sociability schools, seabed type water column and pelagic habitat all had 15-17 negative co-occurrences). Additionally, deep body shape and solitary sociability had relatively many positive and negative co-occurrences. Relatively rare trait categories (e.g. tropical distribution, autumn spawning) had a small number of co-occurrences. At the scale of entire traits, body shape, depth range, mobility and exposure had the highest cumulative positive co-occurrences of all their modalities, while body shape, mobility, habitat type and exposure had the highest cumulative negative cooccurrences. The lowest number of cumulative co-occurrences (both negative and positive) was found for the traits: hermaphroditism, diet, seasonal migrations, seabed type and optimal temperature. 
310

311

312

313

314

315

316

317

318

319

320

321

322

323

324

325

326

327

328

329

330

331

332

333

334

335

336

337

338

339

340

341

342

343

344

345

346

347

348

349

350

351

352

353

354

The Hill-Smith ordination resulted into many axes, each explaining a relatively small variance percentage (in Figure 5, the first two axes presented explain 19\% of cumulative variance). The dendrogram resulting from the hierarchical clustering of the species coordinates (Figure 6), if cut at a high value of dissimilarity (e.g. $70 \%$, not shown in the figure) distinguishes three major groups of pelagic, benthopelagic and benthic species and the associated traits. At lower dissimilarities (42\%), six main groups are extracted. As these groups include in some cases a wide range of species with very different functional roles (e.g. group A includes pelagic species spanning from swordfish and tuna to anchovy and sardine) it was deemed necessary to determine grouping in lower dissimilarity levels (13.5\% as shown in the figure) resulting in the definition of 18, more homogeneous internally, functional groups. The traits characterizing the six major and the 18 minor functional groups are presented in Supplementary Table S2. From both Figures 5 and 6 and the supplementary table, it is evident that while the coarse distinction (six groups: A-F) can indicate the major groupings of nektonic organisms, the grouping at a higher level of similarity can highlight major functional components of the nekton within the ecosystem, like small pelagic species (Group 1) or herbivorous fish (Group 3).

\section{Discussion}

The nekton functional groups identified here can be a useful tool to study the ecology of the Mediterranean Sea, both in analyses using empirical data and in simulation models that utilize functional groups to operate (e.g. Ecopath -Pauly et al., 2000). Despite the fact that, from the clustering of Figure 5, the initial choice would be to divide the dendrogram either in the three major clades (pelagic, benthopelagic and benthic groups) or in the six groups (A-F) identified at $42 \%$ dissimilarity level, it is more informative and reasonable to use a lower dissimilarity that leads to the distinction of groups with different actual functional roles (e.g. 1: small pelagics, 3: vegetation grazers) or with higher homogeneity in traits (like the division the pelagic group A that on average had large size into the species with small size in group 1 and those with larger size in group 2). As nekton can be generally expected to occupy a variety of ecological niches because of the variety in species traits like size, habitat use and diet, it is not surprising to have more functional groups than those found in zooplankton (e.g. Benedetti et al., 2018). Further steps examining only traits related to resource use could shed light into potential inter-specific competition relationships and niche overlap (M. Koutsidi unpublished data).

Violle et al. (2017) underline the importance of functional rarity and the ecology of outliers as complementary to the concept of the traditional taxonomic rarity. While rare species may share traits with more abundant ones, in the case that the traits (and resulting functions) are rare, loss of the species that possess them may significantly alter ecosystem functioning (Jain et al., 2014). This is also relevant to the concept of keystoneness (a keystone species being a species whose importance for its community is disproportionally high in comparison to its abundance -Bond, 2001). Here we document the rarity (even below 5\% of the species total) of autumn spawning (but also winter and all year spawning) as well as that of herbivory. Herbivory is anyway considered a crucial aspect of ecosystem functioning as alterations in herbivory may cause community phase shifts where the main habitat-formers are lost or substituted by very different ones: Verges et al. (2014) have documented this regarding the populations of Siganus sp. that have invaded the Mediterranean Sea, but there are also examples from coral reefs (Hughes et al., 2010) and temperate algal forests (Steneck et al., 2002). Thus, it is important to maintain and regulate the abundance and the rate of renewal of this trait, especially taking into 
355

356

357

358

359

360

361

362

363

364

365

366

367

368

369

370

371

372

373

374

375

376

377

378

379

380

381

382

383

384

385

386

387

388

389

390

391

392

393

394

395

396

397

398

399

account the fact that some of the invading species (e.g. Siganus sp.) in the Mediterranean are herbivorous and competing with resident species (M. Koutsidi, unpublished data). Similar rarity of herbivory has been documented by Beukhof et al. (2019) for marine fish from North Atlantic and Northeast Pacific continental shelf seas (in that work the importance of piscivory is much lower, however the dominant modality is that of generalist feeding, which was not used in the dataset of the present work). It is true that herbivory is also carried out by other, benthic, biota (e.g. echinoderms); however, they have different traits (e.g. mobility) that may change this function. Successful seasonal spawning, like autumn and winter spawning -and also the success of the recruitment that follows it- may be prone to various environmental factors, also possibly affected by anthropogenic effects like fisheries (that are characteristically seasonal in the Mediterranean) or climate change that may decrease the duration of the window-period suitable for spawning (Table 1). The above indicate the clear need for a holistic assessment evaluation of traits including all biotic elements of the ecosystem (plankton, nekton and benthos).

The rarity of other traits like hard seabed type preference may be related to the relatively small extent of this habitat type in the marine environment. Similarly, the low occurrence of long body shape may be related to the scarcity in characteristics of the habitat (e.g. structurally complex habitat for long body shape which here was indeed found to cooccur with cryptic exposure). However, the similarly rare flat body shape cooccurs with soft seabed preference which is a relatively common trait, indicating that trait relationships may be less straightforward. Even though the body-shape trait categories in Beukhof et al. (2019) for North Atlantic and Northeast Pacific are not exactly similar, the long and eel-like body shapes are overall more common there, while the deep body shape tends to be more common in the Mediterranean.

It is important to note that trait rarity should not only be evaluated at the species level, but also weighted with species abundance or biomass to indicate the actual "abundance" of traits in the ecosystem (Violle et al., 2017). E.g. the planktivorous diet trait category may be rare if evaluated using the number of species but very abundant as the small pelagic or benthopelagic species that possess it have very high abundances. Still, the fact that it is shared by only a handful of species may be a risk for ecosystem functioning, especially taking into account the fact that these species are known to have interannual abundance fluctuations. Even more so, some of these species like the European anchovy Engraulis encrasicholus and the European pilchard Sardina pilchardus are under intense fishing pressure and have been shown to be affected by climate (Tzanatos et al., 2013).

The present work confirms that the combinations of functional traits in species of Mediterranean fisheries resources are not random (e.g. Jennings et al., 2002), since the evolutionary process has provided species with certain trait combinations (Gislason et al., 2010). Here we reconfirm that species with a long lifespan also have large body size (Vila-Gispert, Alcaraz \& Garcia-Berthou 2005). Charnov, Gislason \& Pope (2013) note that species only grow to a large body size if natural mortality rates are low, thus their life span is long. The examination of the distribution of species in trait space using a randomization approach similar to Diaz et al. (2016) could provide more definitive results on the non-random distribution of traits.

In the present work, longevity and age at maturity are negatively correlated, in ostensible disagreement with previous studies documenting a positive relationship (Froese \& Binohlan, 2000; Jarić \& Gavcić, 2012). Contrary to these works (where age at maturity is expressed in years), here age at maturity was examined as a percentage of the species lifespan. Indeed, if age 
400 at maturity is expressed in years in our dataset, there is a positive correlation with longevity $401 \quad(\mathrm{r}=0.72, \mathrm{p}<0.001)$; however here we had intended to determine how early or late a species 402 matures regarding its life duration. Therefore, species with a short life span tend to mature 403 relatively late in their lifetime. This can be interpreted, if we take into account that even a short404 lived species needs to have completed an amount of growth to reach a minimum size and 405 biomass for reproduction (Beverton, 1963).

406 407 408 409 410 411 412

The positive relationship between size and trophic level found in this study has also been documented in other works (e.g. Romanuk, Hayward, \& Hutchings 2011). Trophic level increases with increasing body size, because most predators are larger than their prey (Kaiser et al., 2005). Jennings et al. (2002) also point out that, in benthic communities, trophic level and body mass of species have a strong relationship. Additionally, in this study we found a relationship between maximum body length and average depth species distribution. Finally, in this study, non-linear (polynomial) relationships between traits are indicated perhaps because of the existence of sharks and rays in the dataset. Especially their high longevity and low fecundity, result in deviations from the linear pattern.

The co-occurrence analysis indicates some positive and negative associations between pairs of trait modalities. The main characteristics of small pelagic fish (e.g. Sardina pilchardus, Engraulis encrasicolus) have the highest number of positive and negative associations with the other modalities. The traits of the family Sparidae, such as deep body shape, hermaphroditism (e.g. Sparus aurata) and grazing feeding (e.g Sarpa salpa), were found to have a relatively high number of positive associations with other modalities. The detection of relationships between traits is important not only as a way to explore the relationships of characteristics shaping life, but also because it could be useful to predict the possible effects of anthropogenic pressures on these traits. For example, climate change can be expected to favour thermophilic species, thus traits related to high optimum temperatures (high fecundity, deep body shape, high mobility) may be favoured as well. Koutsidi et al. (2016) have documented the removal of specific traits by fisheries; this could also result in modification of traits composition depending on fisheries management. Furthermore, Edeline et al. (2007) have demonstrated that anthropogenic stressors like fishing may act as selective pressures favouring specific traits (in their study slow growth) that are heritable. Law (2000) mentions some examples of phenotypic changes induced by fisheries and discusses the heritability of these traits. Mousseau \& Roff (1987) have documented higher heritability of morphological traits to life-history traits. Law (2000) indicates that heritability in the range of that demonstrated for life history traits, despite being relatively small is still enough to cause substantial selection responses within a small number of generations. The existence of fisheries-induced evolution is now well-documented in traits like growth and maturation (Kuparinen \& Merila, 2007; Enberg et al., 2012) and complex interactions between natural and anthropogenic selection factors acting in opposite directions may exist (Edeline et al., 2007).

The current work has some findings differing from those of Koutsidi et al. (2016), as e.g. the associations of depth with fecundity and optimal temperatures documented here are not reported there. This can be a result of the inclusion of many more species here, but also because of the treatment of traits according to the variable type here and not as categories in all cases. Many rare traits identified like ambushing feeding behavior, flat and long body shape, autumn spawning, cosmopolitan and tropical distribution and low trophic level and fecundity are common in both works while others like long lifespan and distribution in deep water are novel here and again indicate that continuous traits are better analyzed as such. 
446

447

448

449

450

451

452

453

454

455

456

457

458

459

460

461

462

463

464

465

466

467

468

469

470

471

472

473

474

475

476

477

478

479

480

481

482

483

484

485

486

487

488

489

490

491

Naturally (and as shown also here) traits are related. This is not only with regard to life strategies shaped by evolutionary processes (e.g. larger species having longer life duration too), but also as they may be relevant (e.g. diet and trophic level). Still, apart from the trait affinity, and despite the fact that there is the tendency to try to include only functional traits (i.e. more relevant to life cycle and resource use), different traits may still convey different information and still vary (e.g. as shown here piscivorous fish tend to have higher trophic level, but may still span a range of trophic level values depending on their prey). Furthermore, even relevant traits may incorporate information with different significance for ecosystem functioning or resilience (see e.g. the significance of traits regarding tolerance range for variables like temperature and depth in comparison to the optimal values of these factors in Table 5). Thus, depending on the research question, some, even relevant traits can be useful for the evaluation of findings.

Here, we have not limited our analyses to the 13 functional traits (Violle et a., 2007) of our dataset, but also include ten traits that would be rather characterized as ecological (Beauchard et al., 2017). The determination of relationships between functional traits can indicate affinities derived from phylogenetic constraints or indicate life strategies as they have been shaped by evolution. Relationships between ecological traits can indicate the major aspects of organismal distribution in time and space, while relationships among functional traits and ecological traits can indicate the potential environmental filtering that acts on functional traits. It should be noted that, apart from traits that are not related with many others (like age at maturity and fecundity), most traits were found to have significant relationships with both functional and ecological other traits independent of themselves being of a functional or ecological significance, thus showing some level of environmental filtering on functional aspects; however these relationships should also be examined weighted by abundance or biomass. Anthropogenic stressors may also affect differently these two trait types, as e.g. fisheries act on both functional (e.g. life-cycle, behaviour) and ecological (e.g. habitat) aspects of a population, while the effect of climate is primarily ecological (e.g. temperature optimum and range), but both stressors can have indirect effects on other, related, traits.

In this work, we have assigned each species to a single modality per trait. However, it is true that traits can vary across individuals or populations (Violle et el., 2017) and in some cases a species could be assigned to have more than one modality in a quantitative way (e.g. a species spawning from December to April is here assigned to spawn in winter, while alternatively it could be assigned as spawning in $100 \%$ of winter months and $33 \%$ of spring) using fuzzy coding. Such an approach should be evaluated in future works not only regarding the correct assignment of information to modalities, but also to account for species plasticity thus rendering the analyses more realistic (Chevenet et al. 1994). In the same context, while we used one value as representative of a species, trait values may vary across the entire species distribution or the region examined (e.g. there may be differences between the western and eastern Mediterranean, especially in some continuous traits). Additionally, while in many cases, trait datasets are assembled only regarding the mature stages of a species, it is true that juveniles can possess different trait values (e.g. diet). Furthermore, the major part of abundance/biomass of a population may belong to the juvenile stages. An interesting approach would be to enrich trait datasets with distinct trait values between juveniles and adults. Data from monitoring programs regarding population structure (e.g. through the length distribution that is typical in fisheries monitoring) could be used along with community composition for a more realistic depiction of actual trait space occupied. This would be a very valuable expansion of trait datasets and their usage; however, information on juvenile stages might be hard to obtain, especially for non- 
492 commercial species, whose biology is in some cases not fully documented. Finally, basic

493 biological research (especially for the largely unknown deep-sea fish) and assembly of even 494 more extensive trait datasets in terms of species, at least with a focus to the traits that are more 495 representative of functional diversity would help fill the gaps of the trait database, especially 496 with the aim to focus on understudied Mediterranean ecosystems.

497

498

499

500

501

502

503

504

505

506

507

508

509

510

511

512

513

514

515

516

517

518

519

520

521

522

523

524

525

526

527

528

529

530

531

532

533

534

535

536

537

The question as to which traits constitute more fundamental information for ecosystem functioning still pertains. As ecosystem functioning is related to the transfer of energy and material and the regulation and maintenance of ecological processes (Naeem et al. 1999; Bremner, Rogers \& Frid 2006; Paterson, Defew \& Jabour, 2012), traits related to trophic interactions like diet and trophic level (i.e. effect traits according to Lavorel \& Garnier, 2002; Violle et al., 2007; Suding et al., 2008) are of direct significance. Traits affecting these interactions in space and time (mainly response traits according to the same authors), such as habitat and depth distribution, migration, spawning season and even fecundity are also relevant (Table 1). In plants, it has been shown that, in cases where response traits are also effect traits, there can be loss of ecosystem function (Suding et al., 2008). Moving from the scale of nekton to the scale of the entire ecosystem, i.e. incorporating biotic components like plankton and benthos, as functional traits like maximum length and diet/trophic level are key for energy transfer they should be prioritized to be taken into consideration. Pecuchet et al. (2019), investigating ecosystem-wide functional reorganization in the Baltic Sea by examining multi-trophic communities indicate that diet or type of feeding traits are in many cases relevant for many of the groups examined; however, they underline that different traits are involved and demonstrate diverse dynamics among areas. Litchman et al. (2013) refer to the significance of body size as a trait that is related to many others that are worth monitoring for ecosystem studies (like growth rate, stoichiometric requirements, grazing rate and trophic niche breadth), but underline that the choice on which traits to monitor ultimately relies on the questions asked. In this regard, ecological traits regarding spatial and temporal distribution (habitat and seabed type, environmental variable ranges and optima) or occurrence of critical life cycle events like spawning (spawning period and habitat) could also be useful in supplementing this information to describe the spatio-temporal cooccurrence of the different elements for a holistic evaluation of the marine ecosystem.

With the global ocean being under a multitude of anthropogenic effects (e.g. Crain et al., 2009), it is crucial to identify traits that are significant for monitoring human induced alterations in the structure and dynamics of the marine ecosystem. These traits are not only important as descriptors of the marine community (see e.g. the "mean temperature of the catch" -Cheung, Watson \& Pauly, 2013) useful in monitoring, but should also be maintained to some minimum levels, to avoid function loss or the creation of too many empty ecological niches that could more easily be colonized, e.g. by alien species (Givan et al., 2017). Thus, regarding climate change, traits like optimal temperature and temperature range are significant, as communities with a diversity of thermal affinities and narrow ranges of thermal tolerance are more sensitive to climate change (Burrows et al., in press); yet all range-type traits and also distribution seem to have important implications for ecosystem dynamics and resilience. Regarding fisheries effects, size (also because of the various significant relationships it has with other traits and its implications for management) is a crucial trait. Other core biological traits like longevity, fecundity and age at maturity are also important for fisheries management, but also some behavioural traits relevant for the interaction of nekton with fishing gear may bear some importance. Lavorel \& Garnier (2002) and Violle et al. (2007) suggest that traits whose attributes 
538 vary as a response to changes in environmental conditions are response traits, while traits

539 determining the effect of an organism to the environmental conditions, biotic or abiotic are effect

540 traits. While this distinction is both valid and useful, Lavorel \& Garnier (2002) and Suding et al.

541 (2008) have already indicated that a trait can act as both response and effect; in Table 1 we also

542 document that, in some cases, a response trait (e.g. optimal temperature), having been affected

543 by change in environmental conditions may in turn act as an effect trait altering subsequently the

544 dynamics or composition of the community. This is especially important regarding the direct and

545 indirect effects of anthropogenic stressors like fisheries and climate change. The relationships

546 between traits documented here and elsewhere may help explaining the dynamics of nektonic

547 communities (Marquez et al. 2019) and marine ecosystems and also make predictions for future

548 scenarios, as anthropogenic stressors may alter trait composition indirectly (Henderson et al.

549 2019), through selection of associated traits.

550

\section{Conclusions}

552 Relationships between biological traits have long been studied to investigate how evolution has

553

554

555

556

557

558

559

560

561

562

563

564

565

566

567

568

569

570

571 shaped life into form and function and how characteristics are combined into life strategies. However, the study of nektonic trait distribution and combinations presented here can be useful to elucidate trait interactions significant for indirect alterations of ecosystem functioning, especially today, when the marine environment is under a multitude of anthropogenic stressors that can act on specific traits. The documentation of rare traits (like winter and autumn spawning, herbivory, very low or high size or fecundity, hard substrate type and ambushing predation) in species together with the appraisal of the significance of traits at various scales indicates aspects of crucial importance that need to be preserved. Under a more synthetic scope, nektonic functional groups are broadly determined around major aspects of habitat use (pelagic, benthopelagic or benthic), but can be distinguished in more detail showing affinities among and between functional and ecological traits that can be used in the future to understand nektonic communities and model ecosystems. In any case, the documentation of a multitude of relationships between functional and ecological traits found here indicates how the environment, through the delimitation of species distribution in space and time depending on their traits, can filter functional traits, while the validation of functional trait associations hints at functional interdependencies determined by evolution. The findings documented here highlight the traits that should be evaluated and monitored in the future both at the level of nekton or in combination with other major ecosystem components for the assessment of ecosystem functioning and those that should be maintained to ensure ecosystem resilience.

572

\section{3}

574

575

576

\section{References}

578 Ballesteros E. 2006. Mediterranean coralligenous assemblages: A synthesis of present 579 knowledge. Oceanography and Marine Biology - An Annual Review 44, 123-195. DOI:

$58010.1201 / 9781420006391$. 
581 Bamber RN. 1995. The influence of rising background temperature on the effects of marine

582 thermal effluents. Journal of Thermal Biology 20, 105-110. DOI: 10.1016/0306-4565(94)00038-

$583 \mathrm{~K}$.

584 Beauchard O, Veríssimo H, Queirós AM, Herman PMJ. 2017. The use of multiple biological

585 traits in marine community ecology and its potential in ecological indicator development.

586 Ecological Indicators 76, 81-96. DOI: 10.1016/j.ecolind.2017.01.011.

587 Bejarano S, Jouffray JB, Chollett I, Allen R, Roff G, Marshell A, Steneck R, Ferse SCA, Mumby

588 PJ. 2017. The shape of success in a turbulent world: wave exposure filtering of coral reef

589 herbivory. Functional Ecology 31, 1312-1324. DOI: 10.1111/1365-2435.12828.

590 Bellwood DR, Hoey AS, Choat JH. 2003. Limited functional redundancy in high diversity

591 systems: Resilience and ecosystem function on coral reefs. Ecology Letters 6(4), 281-285. DOI:

592 10.1046/j.1461-0248.2003.00432.x.

593 Benedetti F, Gasparini S, Ayata SD. 2016. Identifying copepod functional groups from species

594 functional traits. Journal of Plankton Research, 38, 1, 159-166. DOI: 10.1093/plankt/fbv096.

595 Benedetti F, Vogt M, Righetti, D, Guilhaumon F, Ayata S-D. 2018. Do functional groups of

596 planktonic copepods differ in their ecological niches? .Journal of Biogeography 45, 604-616.

597 DOI: $10.1111 /$ jbi.13166.

598 Beverton RJH. 1963. Maturation, growth and mortality of clupeid and engraulid stocks in

599 relation to fishing. Rapports. Process-Verbaux.du Conseil International pour l'Exploration de la

600 Mer 154, 44-67.

601 Beverton RJH. 1992. Patterns of reproductive strategy parameters in some marine teleost fishes.

602 Journal of Fish Biology 41 (Supplement B), 137-160. DOI: 10.1111/j.1095-

603 8649.1992.tb03875.x.

604 Beverton RJH, Holt SJ. 1959. A review of the lifespans and mortality rates of fish in nature and 605 the relation to growth and other physiological characteristics. In: Colloquia in ageing. V, The

606 lifespan of animals. London: Ciba Foundation, 142-77.

607 Beukhof E, Dencker TS, Palomares MLD, Maureaud A. 2019. A trait collection of marine fish 608 species from North Atlantic and Northeast Pacific continental shelf seas. PANGAEA. DOI:

609 10.1594/PANGAEA.900866.

610 Bianchi CN, Morri C. 2000. Marine biodiversity of the Mediterranean Sea: Situation, problems

611 and prospects for future research. Marine Pollution Bulletin 40, 367-376. DOI: 10.1016/S0025-

$612326 \mathrm{X}(00) 00027-8$.

613 Bond W. 2001. Keystone species - Hunting the snark? Science, 292, 63-64. DOI:

614 10.1126/science.1060793.

615 Bremner J. 2008. Species' traits and ecological functioning in marine conservation and

616 management. Journal of Experimental Marine Biology and Ecology 366 (1-2), 37-47. DOI:

617 10.1016/j.jembe.2008.07.007.

618 Bremner J, Rogers SI, Frid CLJ. 2006. Mathods for describing ecological functioning of marine 619 benthic assemblages using biological traits analysis (BTA). Ecological Indicators 6, 609-622.

620 DOI: 10.1016/j.ecolind.2005.08.026.

621 Burrows MT, Bates AE, Costello MJ, Edwards M, Edgar GJ, Fox CJ, Halpern BS, Hiddink JG,

622 Pinsky ML, Batt RD, Molinos JG, Payne BL, Schoeman DS, Stuart-Smith RD, Poloczanska ES. 
623 in press. Ocean community warming responses explained by thermal affinities and temperature

624 gradients. Nature Climate Change. DOI:10.1038/s41558-019-0631-5.

625 Charnov EL. 1993. Life History Invariants: Some Explorations of Symmetry in Evolutionary

626 Ecology. Oxford: Oxford University Press.

627 Charnov EL, Gislason H, Pope JG. 2013. Evolutionary assembly rules for fish life histories. Fish 628 and Fisheries 14, 213-224. DOI: 10.1111/j.1467-2979.2012.00467.x.

629 Cheung WWL, Watson R, Pauly D. 2013. Signature of ocean warming in global fisheries catch. 630 Nature 497, 365-368. DOI: 10.1038/nature12156.

631 Coll M, Piroddi C, Steenbeek J, Kaschner K, Ben Rais Lasram F, Aguzzi J,Ballesteros E, 632 Bianchi CN, Corbera J, Dailianis T, Danovaro R, Estrada M, Froglia C, Galil BS, Gasol JM, 633 Gertwagen R, Gil J, Guilhaumon F, Kesner-Reyes K, Kitsos M-S, Koukouras A, Lampadariou 634 N, Laxamana E, López-Fé de la Cuadra CM, Lotze HK, Martin D, Mouillot D, Oro D, Raicevich 635 S, Rius-Barile J, Saiz-Salinas JI, Vicente CS, Somot S, Templado J, Turon X, Vafidis D, 636 Villanueva R, Voultsiadou E. 2010. The Biodiversity of the Mediterranean Sea: Estimates, 637 Patterns, and Threats. PLoS ONE 5, e11842. DOI: 10.1371/journal.pone.0011842.

638 Corsini-Foka M, Economidis PS. 2007. Allochthonous and vagrant ichthyofauna in Hellenic 639 marine and estuarine waters. Mediterranan Marine Science 8, 67-123. DOI: 10.12681/mms.163.

640 Costello MJ, Claus S, Dekeyzer S, Vandepitte L, Tuama EO, Lear D, Tyler-Walters H. 2015.

641 Biological and ecological traits of marine species. PeerJ 3:e1201. DOI: 10.7717/peerj.1201.

642 Côté IM., Poulin R. 1995. Parasitism and group size in social animals: a meta-analysis.

643 Behavioral Ecology 6, 159-165. DOI: 10.1093/beheco/6.2.159.

644 Crain CM, Halpern BS, Beck MW, Kappel CV. 2009. Understanding and managing human

645 threats to the coastal marine environment. Annals of the New York Academy of Sciences 1162, 646 39-62. DOI: 10.1111/j.1749-6632.2009.04496.x.

647 Díaz S, Kattge J, Cornelissen JH, Wright IJ, Lavorel S, Dray S, Reu B, Kleyer M, Wirth C, 648 Prentice IC, Garnier E, Bönisch G, Westoby M, Poorter H, Reich PB, Moles AT, Dickie J, 649 Gillison AN, Zanne AE, Chave J, Wright SJ, Sheremet'ev SN, Jactel H, Baraloto C, Cerabolini 650 B, Pierce S, Shipley B, Kirkup D, Casanoves F, Joswig JS, Günther A, Falczuk V, Rüger N, 651 Mahecha MD, Gorné LD. 2016. The global spectrum of plant form and function. Nature, 529 652 (7585), 167-71. DOI: 10.1038/nature16489.de Juan S, Thrush SF, Demestre M. 2007. Functional 653 changes as indicators of trawling disturbance on a benthic community located in a fishing ground 654 (NW Mediterranean Sea). Marine Ecology Progress Series, 334, 117-129. DOI:

$65510.3354 /$ meps334117.

656 Dray S, Dufour A. 2007. The ade4 Package: Implementing the Duality Diagram for Ecologists. 657 Journal of Statistical Software, 22(4), 1-20. DOI: 10.18637/jss.v022.i04.

658 Dutil JD. 1986. Energetic constraints and spawning interval in the anadromous Arctic charr 659 (Salvelinus alpinus). Copeia 1986, 945-955. DOI: 10.2307/1445291.

660 Edworthy C, Strydom N. 2016. Habitat partitioning by juvenile fishes in a temperate estuarine 661 nursery, South Africa. Scientia Marina 80, 151-161. DOI: 10.3989/scimar.04333.01B.

662 Edeline E, Carlson SM, Stige LC, Wintfield IJ, Fletcher JM, James JB, Haugen TO, Vøllestad 663 LA, Stenseth NC. 2007. Trait changes in a harvested population are driven by a dynamic tug-of664 war between natural and harvest selection. Proceedings of the National Academy of Sciences of 665 the United States of America 104:15799-15804. DOI: 10.1073/pnas.0705908104. 
666 Enberg K, Jørgensen C, Dunlop ES, Varpe Ø, Boukal DS, Baulier L, Eliassen S, Heinno M.

667 2012. Fishing-induced evolution of growth: concepts, mechanisms and the empirical evidence:

668 fishing-induced evolution of growth. Marine Ecology, 33: 1-25. DOI: 10.1111/j.1439-

669 0485.2011.00460.x.

670 Engelhard GH, Heino M. 2005. Scale analysis suggests frequent skipping of the second

671 reproductive season in Atlantic herring. Biology Letters 1, 172-175. DOI:

$67210.1098 / \mathrm{rsbl} .2004 .0290$.

673 Erisman B, Heyman W, Kobara S, Ezer T, Pittman S, Aburto-Oropeza O, Nemeth RS. 2017.

674 Fish spawning aggregations: where well-placed management actions can yield big benefits for

675 fisheries and conservation. Fish and Fisheries 18, 128-144. DOI: 10.1111/faf.12132.

676 Fernandez TV, Milazzo M, Badalamenti F, D'Anna G. 2005. Comparison of the fish

677 assemblages associated with Posidonia oceanica after the partial loss and consequent

678 fragmentation of the meadow. Estuarine, Coastal and Shelf Science, 65(4), 645-653. DOI:

679 10.1016/j.ecss.2005.07.010

680 Ferno A, Olsen S. 1994. Marine fish behavior in capture and abundance estimation. Fishing

681 News Books, Oxford: Blackwell Science.

682 Floeter SR, Krohling W, Gasparini JL, Ferreira CEL, Zalmon IR. 2007. Reef fish community

683 structure on coastal islands of the southeastern Brazil: The influence of exposure and benthic

684 cover. Environmental Biology of Fishes 78, 147-160. DOI: 10.1007/s10641-006-9084-6.

685 Francour P. 1997. Fish assemblages of Posidonia oceanica beds at Port-Cros (France, NW

686 Mediterranean): assessment of composition and long-term fluctuations by visual census. Marine

687 Ecology, 18(2), 157-173. DOI: 10.1111/j.1439-0485.1997.tb00434.x.

688 Frelat R, Orio A, Casini M, Lehmann A, Mérigot B, Otto SA, Sguotti C, Möllmann C. 2018. A 689 three-dimensional view on biodiversity changes: spatial, temporal, and functional perspectives 690 on fish communities in the Baltic Sea. ICES Journal of Marine Science 75(7), 2463-2475. DOI:

691 10.1093/icesjms/fsy027.

692 Froese R., Binohlan C. 2000. Empirical relationships to estimate asymptotic length, length at

693 first maturity and length at maximum yield per recruit in fishes, with a simple method to evaluate

694 length frequency data. Journal of Fish Biology, 56, 758-773. DOI: 10.1111/j.1095-

695 8649.2000.tb00870.x.

696 Galil BS. 2007. "Loss or gain? Invasive aliens and biodiversity in the Mediterranean Sea".

697 Marine Pollution Bulletin. Marine Bioinvasions: A collection of reviews. 55, 314-322. DOI:

698 10.1016/j.marpolbul.2006.11.008.

699 Gerlach SA, Hahn AE, Schrage M. 1985. Size spectra of benthic biomass and metabolism.

700 Marine Ecology Progress Series 26, 161-173. DOI: 10.3354/meps026161.

701 Giacomini HC, Shuter BJ, Baum JK. 2016. Size-based approaches to aquatic ecosystems and

702 fisheries science: a symposium in honour of Rob Peters. Canadian Journal of Fisheries and

703 Aquatic Sciences, 73, 471-476. DOI: 10.1139/cjfas-2016-0100.

704 Gislason H, Daan N, Rice JC, Pope JG. 2010. Size, growth, temperature and the natural mortality

705 of marine fish. Fish and Fisheries, 11, 149-158. DOI: 10.1111/j.1467-2979.2009.00350.x.

706 Givan O, Parravicini V, Kulbicki M, Belmaker J. 2017. Trait structure reveals the processes

707 underlying fish establishment in the Mediterranean. Global Ecology and Biogeography 26, 42-

708 153. DOI: $10.1111 /$ geb.12523.

Peer] reviewing PDF | (2019:09:41011:1:1:NEW 20 Dec 2019) 
709 Godin J-GJ, Classon LJ, Abrahams MV. 1988. Group Vigilance and Shoal Size in a Small

710 Characin Fish. Behaviour 104, 29-40. DOI: 10.1163/156853988X00584.

711 Griffith DM, Veech JA, Marsh CJ. 2016. cooccur: Probabilistic species co-occurrence analysis in

712 R. Journal of Statistical Software 69(2), 1-17. DOI: 10.18637/jss.v069.c02.

713 Grubbs FE. 1950. Sample criteria for testing outlying observations. Annals of Mathematical

714 Statistics 21, 27-58. DOI:10.1214/aoms/1177729885.

715 Guidetti P. 2000. Differences among fish assemblages associated with nearshore Posidonia

716 oceanica seagrass beds, rocky-algal reefs and unvegetated sand habitats in the Adriatic Sea.

717 Estuarine, Coastal and Shelf Science, 50(4), 515-529. DOI: 10.1006/ecss.1999.0584

718 Henderson CJ, Gilby BL, Schlacher TA, Connolly RM, Sheaves M, Maxwell PS, Flint N,

719 Borland HP, Martin TS, Gorissen B, Olds AD. 2019. Landscape transformation alters functional

720 diversity in coastal seascapes. Ecography 42, 1-11. DOI:10.1111/ecog.04504.

721 Henriques S, Cardoso P, Cardoso I, Laborde M, Cabral HN, Vasconcelos RP. 2017. Processes

722 underpinning fish species composition patterns in estuarine ecosystems worldwide. Journal of

723 Biogeography 44, 627-639. DOI: 10.1111/jbi.12824.

724 Henseler C, Nordström MC, Törnroos A, Snickars M, Pecuchet L, Lindegren M, Bonsdorff E.

725 2019. Coastal habitats and their importance for the diversity of benthic communities: A species-

726 and trait-based approach. Estuarine, Coastal and Shelf Science 226, 106272. DOI:

727 10.1016/j.ecss.2019.106272.

728 Hill MO, Smith AJ. 1976. Principal Component Analysis of taxonomic data with multi-state

729 discrete characters, Taxon 25, 249-255. DOI:10.2307/1219449.

730 Hoare DJ, Krause J, Peuhkuri N, Godin J-GJ. 2005. Body size and shoaling in fish. Journal of

731 Fish Biology 57, 1351-1366. DOI: 10.1111/j.1095-8649.2000.tb02217.x.

732 Hughes TP, Graham NAJ, Jackson JBC, Mumby PJ, Steneck RS. 2010. Rising to the challenge

733 of sustaining coral reef resilience. Trends in Ecology and Evolution 25, 633-642. DOI:

734 10.1016/j.tree.2010.07.011.

735 Jain M, Flynn DFB, Prager CM, Hart GM, De Van CM, Ahrestani FS, Palmer MI, Bunker DE,

736 Knops JMH, Jouseau CF, Naeem S. 2014. The importance of rare species: a trait-based

737 assessment of rare species contributions to functional diversity and possible ecosystem function

738 in tall-grass prairies. Ecology and Evolution 4, 104-112. DOI: 10.1002/ece3.915.

739 Jarić I, Gavcić Z. 2012. Relationship between the longevity and the age at maturity in long-lived

740 fish: Rikhter/Efanov's and Hoenig's methods. Fisheries Research 129-130, 61-63. DOI:

741 10.1016/j.fishres.2012.06.010.

742 Jennings S. 2005. Size-based analyses of aquatic food webs. In: Belgrano A., Scharler U.M.,

743 Dunne J., Ulanowicz R.E. (eds.): Aquatic Food Webs: An ecosystem approach. Oxford

744 University Press 262 pp.

745 Jennings S, Kaiser MJ, Reynolds JD. 2001. Marine Fisheries Ecology. Blackwell Science,

746 Oxford. 417 pp.

747 Jennings S, Pinnegar JK, Polunin NVC, Warr KJ. 2002. Linking size-based and trophic analyses

748 of benthic community structure. Marine Ecology Progress Series, 226, 77-85. DOI:

749 10.3354/meps226077. 
750 Jonsson B, Jonsson N. 1993. Partial Migration - Niche Shift Versus Sexual-Maturation in

751 Fishes, Reviews in Fish Biology and Fisheries 3, 348-365. DOI: 10.1007/BF00043384.

752 Kaiser MJ, Atrill MJ, Jennings S, Thomas DN, Barnes DKA, Brierley AS, Hiddink JG,

753 Kaartokallio H, Polunin NVC, Williams PJ le B. 2005. Marine Ecology: Processes, Systems and

754 Impacts. Oxford University Press, 557 pp. DOI: 10.1007/s11099-006-0039-0.

755 Kaiser MJ, Clarke KR, Hinz H, Austen MCV, Somerfield PJ, Karakassis I. 2006. Global analysis

756 of response and recovery of benthic biota to fishing. Marine Ecology Progress Series 311, 1-14.

757 DOI: $10.3354 /$ meps311001.

758 Kalogirou S, Corsini-Foka M, Sioulas A, Wennhage H, Pihl L. 2010. Diversity, structure and

759 function of fish assemblages associated with Posidonia oceanica beds in an area of the eastern

760 Mediterranean Sea and the role of non-indigenous species. Journal of Fish Biology, 77, 2338-

761 2357. DOI: 10.1111/j.1095-8649.2010.02817.x.

762 Katselis G, Koutsikopoulos C, Dimitriou E, Rogdakis Y. 2003. Spatial and temporal trends in the

763 composition of the fish barriers fisheries production of the Messolonghi-Etoliko lagoon (western

764 Greek coast). Scientia Marina 67 (4), 501-511. DOI: 10.3989/scimar.2003.67n4501.

765 Kerr SR, Dickie LM. 2001. The biomass spectrum: a predator-prey theory of aquatic production.

766 New York: Columbia University Press.

767 Koutsidi M, Tzanatos E, Machias A, Vassilopoulou V. 2016. Fishing for function: the use of

768 biological traits to evaluate the effects of multispecies fisheries on the functioning of fisheries

769 assemblages. ICES Journal of Marine Science 73(4), 1091-1103. DOI: 10.1093/icesjms/fsw006.

770 Krause J, Godin J-GJ. 1995. Predator preferences for attacking particular prey group sizes:

771 consequences for predator hunting success and prey predation risk. Animal Behaviour 50, 465-

772 473. DOI: 10.1006/anbe.1995.0260.

773 Krause J, Ruxton GD. 2002. Living in groups. Oxford: Oxford University Press.

774 Kuparinen A, Merilä J. 2007. Detecting and managing fisheries-induced evolution. Trends in

775 Ecology \& Evolution 22, 652-659. DOI: 10.1016/j.tree.2007.08.011.

776 Law R. 2000. Fishing, selection, and phenotypic evolution. ICES Journal of Marine Science 57,

777 659-668. DOI: 10.1006/jmsc.2000.0731.

778 Leis JM. 2006. Are Larvae of Demersal Fishes Plankton or Nekton? Advances in Marine

779 Biology 51, 57-141. DOI: 10.1016/S0065-2881(06)51002-8.

780 Lejeusne C., Chevaldonné P., Pergent-Martini C., Boudouresque C. F., Pérez T. (2010): Climate

781 change effects on a miniature ocean: the highly diverse, highly impacted Mediterranean Sea.

782 Trends in Ecology and Evolution 25, 250-260. DOI: 10.1016/j.tree.2009.10.009.

783 Litchman E, Ohman MD, Kiørboe T. 2013. Trait-based approaches to zooplankton communities.

784 Journal of Plankton Research, 35, 473-484. DOI: 10.1093/plankt/fbt019.

785 Loreau M, Naeem S, Inchausti P, Bengtsson J, Grime JP, Hector A, Hooper DU, Huston MA,

786 Raffaelli D, Schmid B, Tilman D, Wardle DA. 2001. Biodiversity and Ecosystem Functioning:

787 Current Knowledge and Future Challenges. Science 294, 804-808. DOI:

788 10.1126/science.1064088.

789 Mariani P, Andersen KH, Visser AW, Barton AD, Kiørboe T. 2013. Control of plankton

790 seasonal succession by adaptive grazing. Limnology and Oceanography 58, 173-184. DOI:

$791 \quad 10.4319 /$ lo.2013.58.1.0173. 
792 Martino EJ, Able KW. 2003. Fish assemblages across the marine to low salinity transition zone 793 of a temperate estuary. Estuarine, Coastal and Shelf Science 56, 969-987. DOI: 10.1016/S0272794 7714(02)00305-0.

795 Matheson RE., Flaherty-Walia KE, Switzer TS, McMichael RH. 2017. The importance of time 796 of day in structuring demersal ichthyofaunal assemblages on the West Florida Shelf. Bulletin of 797 Marine Science 93, 407-437.

798 Marquez JF, Lee AM, Aanes S, Engen S, Herfindal I, Salthaug A, Sæther B. 2019. Spatial 799 scaling of population synchrony in marine fish depends on their life history. Ecology Letters 22, 800 1787-1796. DOI: 10.1111/ele.13360.

801 McLean M, Mouillot D, Auber A. 2018. Ecological and life history traits explain a climate802 induced shift in a temperate marine fish community. Marine Ecology Progress Series 606, pp. 803 175-186. DOI: 10.3354/meps12766.

804 McLusky DS, Elliott M. 2007. Transitional waters: a new approach, semantics or just muddying 805 the waters? Estuarine, Coastal \& Shelf Science, 71, 359-363. DOI: 10.1016/j.ecss.2006.08.025.

806 Moranta J, Palmer M, Morey G, Ruiz A, Morales-Nin B. 2006. Multi-scale spatial variability in 807 fish assemblages associated with Posidonia oceanica meadows in the Western Mediterranean 808 Sea. Estuarine, Coastal and Shelf Science, 68, 579-592. DOI: 10.1016/j.ecss.2006.03.008.

809 Mousseau TA, Roff DA. 1987. Natural selection and the heritability of fitness components. 810 Heredity, 59, 181-197.

811 Moyle PB, Cech Jr JJ. 2004. Fishes: An introduction to Ichthyology. Pearson Benjamin 812 Cummings, 5th edition, $726 \mathrm{pp} .$.

813 Myers N, Mittermeier RA, Mittermeier CG, da Fonseca GAB, Kent J. 2000. Biodiversity 814 hotspots for conservation priorities. Nature, 403, 853-858. DOI: 10.1038/35002501.

815 Naeem S, Chapin FS, Costanza R, Ehrlich PR, Golley FB, Hooper DU, Lawton JH, O'Neill RV, 816 Mooney HA, Sala OE, Symstad AJ, Tilman D. 1999. Biodiversity and Ecosystem Functioning:

817 Maintaining Natural Life Support Processes Issues in Ecology, vol. 4. Washington: Ecological 818 Society of America, 11.

819 Nicolaidou A, Reizopoulou S, Koutsoubas D, Orfanidis S, Kevrekidis T. 2005. Biological 820 components of Greek Lagoonal Ecosystems: An overview. Mediterranean Marine Science, 6 (2), 821 31-50. DOI: 10.12681/mms.184.

822 Occhipinti-Ambrogi A, Savini D. 2003. Biological invasions as a component of global change in 823 stressed marine ecosystems Marine Pollution Bulletin 46, 542-551. DOI: 10.1016/S0025824 326X(02)00363-6.

825 Park TH, Lee CI, Kang CK, Kwak JH, Lee SH, Park HJ (2019). Seasonal Variation in Food Web 826 Structure and Fish Community Composition in the East/Japan Sea. Estuaries and Coasts 42, 1827 15. https://doi.org/10.1007/s12237-019-00530-4.

828 Pasquaud S, Vasconcelos RP, França S, Henriques S, Costa MJ, Cabral H. 2015. Worldwide 829 patterns of fish biodiversity in estuaries: Effect of global vs. local factors. Estuarine, Coastal and 830 Shelf Science 154, 122-128. DOI: 10.1016/j.ecss.2014.12.050.

831 Paterson DM, Defew EC, Jabour J. 2012. Ecosystem function and co-evolution of terminology in 832 marine science and management. In: Solan M., Aspden R.J., Paterson D.M. (editors): Marine 833 biodiversity and ecosystem functioning. Oxford: Oxford University Press, 24-33. 
834 Pauly D., Christensen V., Dalsgaard J., Froese R., Torres F (1998). Fishing down marine food 835 webs. Science 279, 860-863. DOI: 10.1126/science.279.5352.860.

836 Pauly D, Christensen V, Walters C. 2000. Ecopath, Ecosim and Ecospace as tools for evaluating 837 ecosystem impact of fisheries. ICES Journal of Marine Science 57: 697-706. DOI:

838 10.1006/jmsc.2000.0726.

839 Paxton A. B., Revels L. W., Rosemond R. C., Van Hoeck R. V., Lemoine H. R., Taylor J. C., 840 Peterson CH. 2018. Convergence of fish community structure between a newly deployed and an 841 established artificial reef along a five-month trajectory. Ecological Engineering 123, 185-192. 842 DOI: 10.1016/j.ecoleng.2018.09.012.

843 Pecuchet L, Lindegren M, Hidalgo M, Delgado M, Esteban A, Fock HO, Gil de Sola L, Punzón 844 A, Sólmundsson J, Payne MR. 2017. From traits to life-history strategies: Deconstructing fish 845 community composition across European seas. Global Ecology and Biogeography 26(7), 812846 822. DOI: $10.1111 /$ geb.12587.

847 Pecuchet L, Lindegren M, Kortsch S, Całkiewicz J, Jurgensone I, Margonski P, Otto SA, Putnis 848 I, Strāķe S, Nordström MC. 2019. Spatio-temporal dynamics of multi-trophic communities 849 reveal ecosystem-wide functional reorganization. Ecography 42, 1-12. DOI:

850 10.1111/ecog.04643.

851 Pecuchet L, Reygondeau G, Cheung WWL, Licandro P, van Denderen D, Payne MR, Lindegren 852 M (2018). Spatial distribution of life-history traits and their response to environmental gradients 853 across multiple marine taxa. Ecosphere 9(10), e02460. DOI: 10.1002/ecs2.2460.

854 Pereira PHC, Macedo CH, Nunes J d ACC, Marangoni LF d B, Bianchini A. 2018. Effects of 855 depth on reef fish communities: Insights of a "deep refuge hypothesis" from Southwestern 856 Atlantic reefs. PLoS ONE 13(9), e0203072. https://doi.org/10.1371/journal.pone.0203072.

857 Pianka ER. 1970. On r-and K-selection. American Naturalist, 592-597.

858 Pitcher TJ, Parrish JK. 1993. Functions of shoaling behaviour in teleosts. In Pitcher, T. J. (ed.), 859 Behaviour of Teleost Fishes. London: Chapman \& Hall, 363-439.

860 R Core Team 2019. R: A language and environment for statistical computing. R Foundation for 861 Statistical Computing, Vienna, Austria. URL https://www.R-project.org/.

862 Rideout RM, Morgan MJ, Lilly GR. 2006. Variation in the frequency of skipped spawning in 863 Atlantic cod (Gadus morhua) off Newfoundland and Labrador. ICES Journal of Marine Science 864 63, 1101-1110. DOI: 10.1016/j.icesjms.2006.04.014.

865 Rijnsdorp AD, Bastardie F, Bolam SG, Buhl-Mortensen L, Eigaard OR, Hamon KG, Hiddink 866 JG, Hintzen NT, Ivanović A, Kenny A, Laffargue P, Nielsen JR, O'Neill FG, Piet GJ, Polet H, 867 Sala A, Smith C, van Denderen PD, Van Kooten T, Zengin M. 2016. Towards a framework for 868 the quantitative assessment of trawling impact on the seabed and benthic ecosystem. ICES 869 Journal of Marine Science 73, i127-i138. DOI: 10.1093/icesjms/fsv207.

870 Romanuk T, Hayward A, Hutchings JA. 2011. Trophic level scales positively with body size in 871 fishes. Global Ecology and Biogeography, 20, 231-240. DOI: 10.1111/j.1466-

872 8238.2010.00579.x.

873 Schrandt MN, Switzer TS, Stafford CJ, Flaherty-Walia KE, Paperno R, Matheson RE. 2018. 874 Similar habitats, different communities: Fish and large invertebrate assemblages in eastern Gulf 875 of Mexico polyhaline seagrasses relate more to estuary morphology than latitude. Estuarine, 876 Coastal and Shelf Science 213, 217-229. DOI: 10.1016/j.ecss.2018.08.022. 
877 Secor DH 2015. Migration Ecology of Marine Fishes. Baltimore: Johns Hopkins University 878 Press.

879 Solan M, Aspden RJ, Paterson DM. 2012. Marine biodiversity and ecosystem functioning. 880 Oxford: Oxford University Press.

881 Steneck RS, Graham MH, Bourque BJ, Corbett D, Erlandson JM, Estes JA, Tegner MJ. 2002.

882 Kelp forest ecosystems: biodiversity, stability, resilience and future. Environmental Conservation 883 29, 436-459. DOI: 10.1017/S0376892902000322.

884 Tornroos A, Bonsdorff E. 2012. Developing the multitrait concept for functional diversity:

885 lessons from a system rich in functions but poor in species. Ecological Applications 22(8): 2221886 2236. DOI: 10.1890/11-2042.1.

887 Tserpes G, Tzanatos E, Peristeraki P. 2011. Spatial management of the Mediterranean bottom-

888 trawl fisheries: The case of the southern Aegean Sea. Hydrobiologia 670, 267-274. DOI:

889 10.1007/s10750-011-0667-7.

890 Tzanatos E, Somarakis S, Tserpes G, Koutsikopoulos C. 2006. Identifying and classifying small891 scale fisheries métiers in the Mediterranean: a case study in the Patraikos Gulf, Greece. Fisheries 892 Research 81, 158-168. DOI: 10.1016/j.fishres.2006.07.007.

893 Vasilakopoulos P, Raitsos DE, Tzanatos E, Maravelias CD. 2017. Resilience and regime shifts in 894 a marine biodiversity hotspot. Scientific Reports 7(1), 13647. DOI: 10.1038/s41598-017-138528959.

896 Vega-Cendejas ME, de Santillana MH. 2019. Demersal fish assemblages and their diversity on 897 the Yucatan continental shelf: Gulf of Mexico. Regional Studies in Marine Science 29, 100640. 898 DOI: 10.1016/j.rsma.2019.100640.

899 Vergés A, Steinberg PD, Hay ME, Poore AGB, Campbell AH, Ballesteros E, Heck KL, Booth 900 DJ, Coleman MA, Feary DA, Figueira W, Langlois T, Marzinelli EM, Mizerek T, Mumby PJ, 901 Nakamura Y, Roughan M, van Sebille E, Gupta AS, Smale DA, Tomas F, Wernberg T, Wilson 902 SK. (2014). The tropicalization of temperate marine ecosystems: climate-mediated changes in 903 herbivory and community phase shifts, Proceedings of the Royal Society B: Biological Sciences, 904 281. 20140846. DOI: 10.1098/rspb.2014.0846.

905 Vila-Gispert A, Alcaraz C, García-Berthou E. 2005. Life-history traits of invasive fish in small

906 Mediterranean streams. Biological Invasions 7(1), 107. DOI: 10.1007/s10530-004-9640-y

907 Villéger S, BrosseS, Mouchet M, Mouillot D, Vanni MJ. 2017. Functional ecology of fish: 908 current approaches and future challenges. Aquatic Sciences 79, 783-801. DOI: 10.1007/s00027909 017-0546-z.

910 Violle C, Navas ML, Vile D, Kazakou E, Fortunel C, Hummel I, Garnier E. 2007. Let the 911 concept of trait be functional!. Oikos 116(5), 882-892. DOI: 10.1111/j.0030-1299.2007.15559.x.

912 Violle C, Thuiller W, Mouquet N, Munoz F, Kraft NJB, Cadotte MW, Livingstone SW, Mouillot 913 D. 2017. Functional Rarity: The Ecology of Outliers. Trends in Ecology and Evolution 32(5), 914 356-367. DOI: 10.1016/j.tree.2017.02.002.

915 Winemiller KO, Rose KA. 1992. Patterns of life-history diversification in North American 916 fishes: implications for population regulation. Canadian Journal of Fisheries and Aquatic 917 Sciences, 49, 2196-2218. DOI: 10.1139/f92-242. 
918 Wooton RJ. 1999. Ecology of Teleost fishes. 2nd Edition, Dordrecht: Kluwer Academic 919 Publishers, Fish and Fisheries Series 24.

920 Zar JH. 1999. Biostatistical analysis, 4th ed. Englewood Cliffs, NJ: Prentice-Hall.

921 


\section{Table $\mathbf{1}$ (on next page)}

Significance of traits at the level of species, community, ecosystem functioning and anthropogenic effects.

NR: Not relevant. References with explanation/examples are indicated with numbers corresponding to in-text citations following and are listed in detail in the Reference list.

${ }^{1}$ Ballesteros (2006), ${ }^{2}$ Bamber (1995), ${ }^{3}$ Beauchard et al. (2017), ${ }^{4}$ Charnov, Gislason \& Pope (2013), ${ }^{5}$ Cheung, Watson \& Pauly D. (2013), ${ }^{6}$ Coll et al. (2010), ${ }^{7}$ Costello et al. (2015), ${ }^{8}$ Côté \& Poulin (1995), ${ }^{9}$ Dutil (1986), ${ }^{10}$ Edworthy \& Strydom (2016), ${ }^{11}$ Engelhard \& Heino (2005),

${ }^{12}$ Erisman et al. (2017), ${ }^{13}$ Ferno \& Olsen (1994), ${ }^{14}$ Floeter et al. (2007), ${ }^{15}$ Galil (2007), ${ }^{16}$ Gerlach, Hahn \& Schrage (1985), ${ }^{17}$ Giacomini, Shuter \& Baum (2016), ${ }^{18}$ Givan et al. (2017), ${ }^{19}$ Godin, Classon \& Abrahams (1988), ${ }^{20}$ Henriques et al. (2017), ${ }^{21}$ Henseler et al. (2019), ${ }^{22}$ Hoare et al. (2005), ${ }^{23}$ Jennings (2005), ${ }^{24}$ Jennings, Kaiser \& Reynolds (2001), ${ }^{25}$ Jonsson \& Jonsson (1993), ${ }^{26}$ Kaiser et al. (2005), ${ }^{27}$ Kaiser et al. (2006), ${ }^{28}$ Kalogirou et al. (2010), ${ }^{29}$ Katselis et al. (2003), ${ }^{30} \mathrm{Kerr} \&$ Dickie (2001), ${ }^{31}$ Krause \& Godin (1995), ${ }^{32}$ Krause \& Ruxton (2002), ${ }^{33}$ Leis (2006), ${ }^{34}$ Lejeusne et al. (2010), ${ }^{35}$ Loreau et al. (2001), ${ }^{36}$ Mariani et al. (2013), ${ }^{37}$ Martino \& Able (2003), ${ }^{38}$ Matheson et al. (2017), ${ }^{39}$ McLusky \& Elliott (2007), ${ }^{40}$ Moyle \& Cech (2004), ${ }^{41}$ OcchipintiAmbrogi \& Savini (2003), ${ }^{42}$ Park et al. (2019), ${ }^{43}$ Pasquaud et al. (2015), ${ }^{44}$ Pauly et al. (1998), ${ }^{45}$ Paxton et al. (2018), ${ }^{46}$ Pereira (2018), ${ }^{47}$ Pianka (1970), ${ }^{48}$ Pitcher \& Parrish (1993), ${ }^{49}$ Rideout, Morgan \& Lilly (2006), ${ }^{50}$ Rijnsdorp et al. (2016), ${ }^{51}$ Schrandt et al. (2018), ${ }^{52}$ Secor (2015),

${ }^{53}$ Solan, Aspden \& Paterson (2012), ${ }^{54}$ Tserpes, Tzanatos \& Peristeraki (2011), ${ }^{55}$ Tzanatos et al. (2006), ${ }^{56}$ Vasilakopoulos et al. (2017), ${ }^{57}$ Vega-Cendejas \& de Santillana (2019), ${ }^{58}$ Winemiller \& 
Rose (1992), ${ }^{59}$ Wooton (1999) 


\begin{tabular}{|c|c|c|c|c|c|}
\hline \multirow[b]{2}{*}{$a / a$} & \multirow[b]{2}{*}{ Trait (example) } & \multicolumn{4}{|c|}{ Significance or implications at the level of: } \\
\hline & & Population/species & Community & Ecosystem & Anthropogenic effects \\
\hline \multirow[t]{2}{*}{1} & $\begin{array}{l}\text { Longevity }(5 \\
\text { years) }\end{array}$ & $\begin{array}{l}\text { Longer lifespan increases reproductive } \\
\text { success over time }\end{array}$ & $\begin{array}{l}\text { Higher longevity renders individual } \\
\text { more important both as prey and as a } \\
\text { predator as more instances of } \\
\text { predation }\end{array}$ & $\begin{array}{l}\text { Longevity is related with natural } \\
\text { mortality and thus with energy } \\
\text { transfer in the ecosystem }{ }^{4}\end{array}$ & $\begin{array}{l}\text { Longevity and age at maturity are } \\
\text { related with the ability to recover from } \\
\text { anthropogenic disturbance }{ }^{27,50}\end{array}$ \\
\hline & & $\begin{array}{l}\text { May indicate population stability over } \\
\text { time and potential of the various life } \\
\text { stages to disperse }^{7}\end{array}$ & & & \\
\hline \multirow[t]{2}{*}{2} & $\begin{array}{l}\text { Age-at-maturity } \\
\text { (30\% of lifespan) }\end{array}$ & $\begin{array}{l}\text { Early maturity may increase resilience } \\
\text { in unfavourable environmental } \\
\text { conditions }{ }^{2}\end{array}$ & NR & $\begin{array}{l}\text { Ecosystem characteristics (e.g. } \\
\text { productivity) may enhance or delay } \\
\text { maturation }\end{array}$ & $\begin{array}{l}\text { Longevity and age at maturity are } \\
\text { related with the ability to recover from } \\
\text { anthropogenic disturbance }{ }^{50}\end{array}$ \\
\hline & & Associated with cessation of growth ${ }^{25}$ & & & $\begin{array}{l}\text { Early maturation may increase } \\
\text { resilience in high exploitation rates. } \\
\text { Maturity significant for fisheries } \\
\text { management (measures planned to } \\
\text { ensure population part achieves sexual } \\
\text { maturity) }\end{array}$ \\
\hline 3 & $\begin{array}{l}\text { Fecundity (5-10 } \\
\text { eggs) }\end{array}$ & $\begin{array}{l}\text { If low should ensure offspring survival- } \\
\text { population fitness, as energy allocated } \\
\text { to survival of offspring or fecundity } \\
\text { (r/K-selection strategy) })^{47}\end{array}$ & $\begin{array}{l}\text { High fecundity means higher } \\
\text { abundance of young "defenceless" } \\
\text { stages (eggs, larvae) that are possible } \\
\text { prey for other populations, but higher } \\
\text { inter-specific competition later on }{ }^{2}\end{array}$ & $\begin{array}{l}\text { As it provides easy-to-capture and rich } \\
\text { in energy prey (compared to adult } \\
\text { prey) may influence energy flow rates }\end{array}$ & $\begin{array}{l}\text { Together with mortality until } \\
\text { recruitment may affect stock size } \\
\text { which is very relevant for fisheries }{ }^{24}\end{array}$ \\
\hline \multirow[t]{2}{*}{4} & $\begin{array}{l}\text { Hermaphroditism } \\
\text { (gonochoristic) }\end{array}$ & $\begin{array}{l}\text { Sexual maturity of the second (in } \\
\text { succession) sex must be achieved } \\
\text { through survival to guarantee } \\
\text { successful spawning and recruitment }\end{array}$ & NR & NR & $\begin{array}{l}\text { As both sex ratio and gear selectivity } \\
\text { change with size, exploitation of one } \\
\text { size part of the population may affect } \\
\text { sex ratio and possibly reproductive } \\
\text { success. }\end{array}$ \\
\hline & & $\begin{array}{l}\text { Size is important in determining male } \\
\text { reproductive success }{ }^{59}\end{array}$ & & & \\
\hline
\end{tabular}




\begin{tabular}{|c|c|c|c|c|c|}
\hline \multirow[b]{2}{*}{$\mathrm{a} / \mathrm{a}$} & \multirow[b]{2}{*}{ Trait (example) } & \multicolumn{4}{|c|}{ Significance or implications at the level of: } \\
\hline & & Population/species & Community & Ecosystem & Anthropogenic effects \\
\hline 5 & $\begin{array}{l}\text { Maximum } \\
\text { length }(20 \mathrm{~cm})\end{array}$ & $\begin{array}{l}\text { Related to individual biomass, food } \\
\text { web position, abundance, metabolic } \\
\text { rates, and dispersal }\end{array}$ & $\begin{array}{l}\text { As in the marine ecosystem there is an } \\
\text { "eat what is smaller" pattern, there } \\
\text { has to be some variability in species } \\
\text { sizes to support a community }{ }^{77,30}\end{array}$ & $\begin{array}{l}\text { Related to energy flow in the } \\
\text { ecosystem (because of association } \\
\text { with trophic level/diet) and resulting } \\
\text { food webs }{ }^{16,23}\end{array}$ & $\begin{array}{l}\text { Relevant for fisheries (with regard to } \\
\text { body shape) for selectivity } 24\end{array}$ \\
\hline 6 & Body form (flat) & $\begin{array}{l}\text { Related to position in the water } \\
\text { column/habitat, diet/potential prey, } \\
\text { activity }\end{array}$ & $\begin{array}{l}\text { Because of association with habitat, } \\
\text { specific communities may have higher } \\
\text { frequencies of some body forms }\end{array}$ & Not relevant & $\begin{array}{l}\text { Related to the way fishing gear may } \\
\text { affect selectivity (together with size) }{ }^{24}\end{array}$ \\
\hline 7 & $\begin{array}{l}\text { Optimal depth } \\
(0-50 \mathrm{~m})\end{array}$ & $\begin{array}{l}\text { Physical factor determining potential } \\
\text { species habitat }{ }^{7}\end{array}$ & $\begin{array}{l}\text { Depth is a major factor shaping marine } \\
\text { communities }^{46,57}\end{array}$ & $\begin{array}{l}\text { Depth may affect productivity and } \\
\text { energy flow as e.g. below the euphotic } \\
\text { zone the lack of primary production } \\
\text { modifies trophic links. Also effects of } \\
\text { elements like critical depth or seagrass } \\
\text { bed distribution }{ }^{27}\end{array}$ & $\begin{array}{l}\text { Different gears and fishing sectors are } \\
\text { often operating in different depths } \\
\text { resulting in different communities } \\
\text { prone to exploitation and resulting } \\
\text { catch composition }{ }^{54}\end{array}$ \\
\hline 8 & $\begin{array}{l}\text { Optimal } \\
\text { temperature } \\
(25-30 \circ C)\end{array}$ & $\begin{array}{l}\text { Defines optimal temperature } \\
\text { conditions for population fitness. May } \\
\text { affect movement between water } \\
\text { masses (behavioural } \\
\text { thermoregulation) and thus } \\
\text { abundance and distribution }\end{array}$ & $\begin{array}{l}\text { Due to climate change can shift to } \\
\text { dominance of more thermophilic } \\
\text { species }^{34}\end{array}$ & NR & $\begin{array}{l}\text { More thermophilic species may appear } \\
\text { more frequently in the catches } s^{5,56}\end{array}$ \\
\hline 9 & $\begin{array}{l}\text { Habitat type } \\
\text { (benthic) }\end{array}$ & $\begin{array}{l}\text { Populations are closely associated to } \\
\text { pelagic or benthic habitat or migrate } \\
\text { between them }\end{array}$ & $\begin{array}{l}\text { Specific habitats are characterised by } \\
\text { specific communities }{ }^{1,28}\end{array}$ & $\begin{array}{l}\text { Effect of seabed type on ecosystem } \\
\text { functioning expected to be significant } \\
\text { as both are related to biodiversity and } \\
\text { its attributes }{ }^{35}\end{array}$ & $\begin{array}{l}\text { Has implications for target species } \\
\text { abundance and bycatch (thus fishing } \\
\text { gear use) })^{55}\end{array}$ \\
\hline 10 & $\begin{array}{l}\text { Distribution } \\
\text { (tropical) }\end{array}$ & $\begin{array}{l}\text { Related to proximity to the geographic } \\
\text { distribution of the area examined (if } \\
\text { e.g. through Gibraltar or Suez in the } \\
\text { Med) and could be associated to } \\
\text { favourable environmental conditions }\end{array}$ & $\begin{array}{l}\text { Species of alien distribution (invasive) } \\
\text { species may dominate the community } \\
\text { through colonisation of empty } \\
\text { niches/lack of "natural enemies"18 }\end{array}$ & NR & $\begin{array}{l}\text { Climate change or other } \\
\text { environmental changes may be forcing } \\
\text { changes in distribution paterns }{ }^{15,41}\end{array}$ \\
\hline
\end{tabular}




\begin{tabular}{|c|c|c|c|c|c|}
\hline \multirow[b]{2}{*}{$\mathrm{a} / \mathrm{a}$} & \multirow[b]{2}{*}{ Trait (example) } & \multicolumn{4}{|c|}{ Significance or implications at the level of: } \\
\hline & & Population/species & Community & Ecosystem & Anthropogenic effects \\
\hline 11 & $\begin{array}{l}\text { Sea bed type } \\
\text { (hard) }\end{array}$ & $\begin{array}{l}\text { Physical factor determining potential } \\
\text { species habitat }^{7}\end{array}$ & $\begin{array}{l}\text { Specific habitats host and are } \\
\text { characterized by specific } \\
\text { communities } \text { s.28 }^{1,28}\end{array}$ & $\begin{array}{l}\text { Effect of seabed type on ecosystem } \\
\text { functioning expected to be significant } \\
\text { as both are related to biodiversity and } \\
\text { its attributes }{ }^{35,53}\end{array}$ & $\begin{array}{l}\text { Has implications for target species } \\
\text { abundance and bycatch (thus gear } \\
\text { use) })^{55}\end{array}$ \\
\hline 12 & $\begin{array}{l}\text { Spawning } \\
\text { habitat (pelagic) }\end{array}$ & $\begin{array}{l}\text { Spawning habitat determines the } \\
\text { nature and intensity of hazards } \\
\text { encountered by eggs and larvae }{ }^{33,59}\end{array}$ & $\begin{array}{l}\text { May determine seasonal communities } \\
\text { as a result of spawning seasonality and } \\
\text { also of populations feeding on eggs } \\
\text { and juveniles }\end{array}$ & $\begin{array}{l}\text { If spawning habitat different from } \\
\text { adult stage habitat may be relevant to } \\
\text { benthopelagic coupling } 33,52\end{array}$ & $\begin{array}{l}\text { May create aggregations prone to } \\
\text { fisheries }^{12}\end{array}$ \\
\hline \multirow[t]{2}{*}{13} & $\begin{array}{l}\text { Temperature } \\
\text { range } \\
\text { (eurythermal) }\end{array}$ & $\begin{array}{l}\text { May increase population resilience to } \\
\text { abrupt temperature changes or ability } \\
\text { to change environment }\end{array}$ & $\begin{array}{l}\text { Eurythermal species may dominate } \\
\text { community under climate } \\
\text { change/frequent weather changes }\end{array}$ & NR & $\begin{array}{l}\text { May increase population resilience to } \\
\text { climate change, invasion rates and } \\
\text { appearance in the fisheries catch }\end{array}$ \\
\hline & & & & & $\begin{array}{l}\text { Eurythermal species may be favoured } \\
\text { in thermal pollution sites }{ }^{2}\end{array}$ \\
\hline 14 & $\begin{array}{l}\text { Salinity range } \\
\text { (stenohaline) }\end{array}$ & $\begin{array}{l}\text { May be related to population ability to } \\
\text { approach/enter productive habitats } \\
\text { like estuaries \& lagoons }\end{array}$ & $\begin{array}{l}\text { Shapes communities of brackish } \\
\text { waters, e.g. along salinity } \\
\text { gradients }^{20,39,43}\end{array}$ & $\begin{array}{l}\text { Relevant to matter \& energy transfer } \\
\text { between the ocean and brackish } \\
\text { waters through euryhaline species }{ }^{37}\end{array}$ & $\begin{array}{l}\text { Shapes the resources exploited by } \\
\text { fisheries in brackish environments (e.g. } \\
\text { lagoon fisheries) }{ }^{29}\end{array}$ \\
\hline 15 & $\begin{array}{l}\text { Depth range } \\
\text { (eurybathic) }\end{array}$ & $\begin{array}{l}\text { Eurybathic species have more } \\
\text { potential habitat and might be more } \\
\text { resilient to habitat loss }\end{array}$ & $\begin{array}{l}\text { Communities dominated by eurybathic } \\
\text { species may be more resilient to } \\
\text { environmental changes and } \\
\text { disturbance }\end{array}$ & $\begin{array}{l}\text { Eurybathic species may transfer } \\
\text { energy through depth zones and } \\
\text { contribute to benthopelagic coupling }\end{array}$ & $\begin{array}{l}\text { More eurybathic species may be more } \\
\text { resilient to habitat degradation by } \\
\text { fisheries or other anthropogenic } \\
\text { effects }\end{array}$ \\
\hline 16 & $\begin{array}{l}\text { Seasonal } \\
\text { migrations } \\
\text { (migratory) }\end{array}$ & $\begin{array}{l}\text { Can change the population ecological } \\
\text { status, may lead to a seasonal } \\
\text { (periodic) life strategy and shape } \\
\text { seasonal energy needs }{ }^{52,58}\end{array}$ & $\begin{array}{l}\text { Community will change seasonally, } \\
\text { qualitatively and quantitatively }{ }^{42}\end{array}$ & $\begin{array}{l}\text { Can have impact on energy flow, } \\
\text { creating seasonal dynamics }{ }^{52}\end{array}$ & $\begin{array}{l}\text { Many fisheries are based on seasonal } \\
\text { migrations for fishing grounds or even } \\
\text { operation of specific gears (e.g. lagoon } \\
\text { fisheries) }\end{array}$ \\
\hline 17 & $\begin{array}{l}\text { Trophic level } \\
(3.5-4.2)\end{array}$ & $\begin{array}{l}\text { Derived from the type and frequency } \\
\text { of trophic objects in its diet }{ }^{7}\end{array}$ & $\begin{array}{l}\text { Influence on other species abundance } \\
\text { and community structure and } \\
\text { dynamics }^{7}\end{array}$ & $\begin{array}{l}\text { May alter nutrient cycling in the } \\
\text { ecosystem }\end{array}$ & $\begin{array}{l}\text { Depending on exploitation removing } \\
\text { part of the trophic network may result } \\
\text { in fishing down the food web }{ }^{44}\end{array}$ \\
\hline 18 & $\begin{array}{l}\text { Diet } \\
\text { (zooplankton) }\end{array}$ & Determines food web position ${ }^{7}$ & $\begin{array}{l}\text { Influence on other species abundance } \\
\text { and community structure and } \\
\text { dynamics }\end{array}$ & $\begin{array}{l}\text { May alter nutrient cycling in the } \\
\text { ecosystem }{ }^{3}\end{array}$ & $\begin{array}{l}\text { Relevant to fishing gear mode of } \\
\text { operation exploiting diet (hook and } \\
\text { line gears e.g. longlines) and } \\
\text { associated target species \& catch } \\
\text { composition }\end{array}$ \\
\hline
\end{tabular}




\begin{tabular}{|c|c|c|c|c|c|}
\hline \multirow[b]{2}{*}{$a / a$} & \multirow[b]{2}{*}{ Trait (example) } & \multicolumn{4}{|c|}{ Significance or implications at the level of: } \\
\hline & & Population/species & Community & Ecosystem & Anthropogenic effects \\
\hline 19 & $\begin{array}{l}\text { Spawning period } \\
\text { (spring) }\end{array}$ & $\begin{array}{l}\text { Shapes the period that the population } \\
\text { must feed to prepare spawning and } \\
\text { non-feeding period. May be associated } \\
\text { with "weak" period (bad condition) } \\
\text { after spawning }\end{array}$ & $\begin{array}{l}\text { May shape feeding interactions and } \\
\text { trophic links within the community } \\
\text { seasonally, both as a result of preying } \\
\text { on eggs and larvae and, secondarily, } \\
\text { because of the seasonal pattern of } \\
\text { recruitment }^{10}\end{array}$ & $\begin{array}{l}\text { Is affected by suitability of the } \\
\text { environmental conditions for eggs \& } \\
\text { larvae. Is affected by energy supply } \\
\text { (low energy may result in delay or } \\
\text { skipping spawning). As the spawning } \\
\text { period generates eggs and larvae it } \\
\text { provides potential prey }{ }^{49,59}\end{array}$ & $\begin{array}{l}\text { Seasonality of fisheries may lead to } \\
\text { unsuccessful spawning and result in } \\
\text { few individuals recruited }\end{array}$ \\
\hline 20 & $\begin{array}{l}\text { Feeding type } \\
\text { (plankton) }\end{array}$ & $\begin{array}{l}\text { Related to the diet and the trophic } \\
\text { level through the relative size and } \\
\text { mobility of the prey in comparison to } \\
\text { the predator }{ }^{7}\end{array}$ & $\begin{array}{l}\text { By shaping diet can affect the } \\
\text { community composition }\end{array}$ & $\begin{array}{l}\text { Related to prey community } \\
\text { composition and lower trophic level } \\
\text { succession patterns }{ }^{36}\end{array}$ & $\begin{array}{l}\text { Relevant to fishing gear mode of } \\
\text { operation exploiting feeding behaviou } \\
\text { (hook and line gears e.g. trolling lines, } \\
\text { longlines) and associated target } \\
\text { species \& catch composition }{ }^{24}\end{array}$ \\
\hline \multirow[t]{2}{*}{21} & $\begin{array}{l}\text { Sociability } \\
\text { (schools) }\end{array}$ & $\begin{array}{l}\text { Benefits like predation avoidance, } \\
\text { food location and foraging strategy, } \\
\text { improvement of reproductive } \\
\text { success }^{59}\end{array}$ & $\begin{array}{l}\text { Schooling important in shaping } \\
\text { communities regarding hydrodynamic } \\
\text { characteristics }^{14}\end{array}$ & $\begin{array}{l}\text { Schooling/pelagic fish may colonise } \\
\text { new habitats (e.g. reefs) more easily }\end{array}$ & $\begin{array}{l}\text { Relevant to fishing gear mode of } \\
\text { operation exploiting gregarious fish } \\
\text { behaviour (e.g. purse seines) and } \\
\text { associated target species \& catch } \\
\text { composition }{ }^{24}\end{array}$ \\
\hline & & $\begin{array}{l}\text { Costs like competition for food or } \\
\text { mate, predator attraction, disease } \\
\text { transmission }\end{array}$ & & & $\begin{array}{l}\text { Schooling/pelagic fish may colonise } \\
\text { new artificial habitats (e.g. reefs) more } \\
\text { easily }{ }^{45}\end{array}$ \\
\hline \multirow[t]{2}{*}{22} & $\begin{array}{l}\text { Exposure } \\
\text { (cryptic- } \\
\text { temporarily) }\end{array}$ & $\begin{array}{l}\text { Population must balance ability to } \\
\text { graze/predate and predation } \\
\text { avoidance }\end{array}$ & $\begin{array}{l}\text { Depending on conditions (e.g. habitat } \\
\text { type) cryptic species may dominate } \\
\text { communities }{ }^{51}\end{array}$ & NR & NR \\
\hline & & $\begin{array}{l}\text { Population (especially cryptic) may } \\
\text { have developed diel activity rhythms }{ }^{38}\end{array}$ & $\begin{array}{l}\text { Level of exposure and cryptic } \\
\text { behaviour relevant to differences in } \\
\text { diel community composition }{ }^{38}\end{array}$ & & \\
\hline 23 & Mobility (high) & $\begin{array}{l}\text { Indicates a dispersal potential and a } \\
\text { more or less mobile lifestyle }{ }^{7}\end{array}$ & $\begin{array}{l}\text { Might differentiate pelagic (more } \\
\text { motile) from benthic (more static) } \\
\text { communities }\end{array}$ & $\begin{array}{l}\text { May be relevant to transfer of energy } \\
\text { between ecosystems or benthopelagic } \\
\text { coupling }\end{array}$ & $\begin{array}{l}\text { Relevant to fishing gear mode of } \\
\text { operation exploiting fish motility } \\
\text { behaviour (e.g. nets) and associated } \\
\text { target species \& catch composition } 13,24\end{array}$ \\
\hline
\end{tabular}




\section{Table 2 (on next page)}

List of traits used in the analyses, trait type (functional/ecological), variable type and categories/modalities used for categorical traits.

CON: Continuous. RAN: Continuous, provided as a range for most/all species. CAT:

Categorical. *as \% of maximum age. ${ }^{* *}$ scale of eggs/juveniles per spawn, maximum value indicated. ***indicating that food items have negligible or low mobility related to predator. 


\begin{tabular}{|c|c|c|c|c|c|c|c|c|}
\hline Trait & Trait type & $\begin{array}{l}\text { Variable } \\
\text { type }\end{array}$ & Trait categorie & Imodalities (in cas & of categorical trait) & & & \\
\hline Longevity & Functional & $\mathrm{CON}$ & & & & & & \\
\hline Age at maturity* & Functional & $\mathrm{CON}$ & & & & & & \\
\hline Fecundity** & Functional & RAN & & & & & & \\
\hline Gonochorism & Functional & CAT & Gonochoristic & Hermaphrodite & & & & \\
\hline Maximum length & Functional & $\mathrm{CON}$ & & & & & & \\
\hline Body shape & Functional & CAT & Flat & Long & Deep & Atractoid & Rounded & \\
\hline Optimal depth & Ecological & RAN & & & & & & \\
\hline $\begin{array}{l}\text { Optimal } \\
\text { temperature }\end{array}$ & Ecological & RAN & & & & & & \\
\hline Habitat type & Ecological & CAT & Pelagic & Benthic & Benthopelagic & & & \\
\hline Distribution & Ecological & CAT & Global & Temperate & Tropical & Subtropical & & \\
\hline $\begin{array}{l}\text { Seabed } \\
\text { morphology }\end{array}$ & Ecological & CAT & Open sea & Soft & Hard & Variable & & \\
\hline $\begin{array}{l}\text { Spawning } \\
\text { habitat }\end{array}$ & Ecological & CAT & Pelagic & Benthic & & & & \\
\hline $\begin{array}{l}\text { Temperature } \\
\text { range }\end{array}$ & Ecological & CAT & Stenothermal & Eurythermal & & & & \\
\hline Salinity range & Ecological & CAT & Stenohaline & Euryhaline & & & & \\
\hline Depth range & Ecological & CAT & Eurybathic & Stenobathic & & & & \\
\hline $\begin{array}{l}\text { Seasonally } \\
\text { migratory }\end{array}$ & Ecological & CAT & Migratory & Non-migratory & & & & \\
\hline Trophic level & Functional & RAN & & & & & & \\
\hline Diet & Functional & CAT & Herbivore & Zoobenthivore & $\begin{array}{l}\text { Zoobenthivore- } \\
\text { Hyperbenthos }\end{array}$ & Omnivore & Zooplankton & Piscivore \\
\hline Spawning period & Functional & CAT & Winter & Spring & Summer & Autumn & All year & \\
\hline $\begin{array}{l}\text { Feeding } \\
\text { behaviour }^{* * *}\end{array}$ & Functional & CAT & Grazer $^{* * *}$ & $\begin{array}{l}\text { Active } \\
\text { predator }\end{array}$ & $\begin{array}{l}\text { Ambushing } \\
\text { predator }\end{array}$ & & & \\
\hline Sociability & Functional & CAT & Schools & $\begin{array}{l}\text { Shoals-large } \\
\text { groups }(>10)\end{array}$ & $\begin{array}{l}\text { Small groups } \\
(<\sim 10)\end{array}$ & Solitary & & \\
\hline Exposure & Functional & CAT & Free & $\begin{array}{l}\text { Cryptic } \\
\text { (permanently) }\end{array}$ & $\begin{array}{l}\text { Cryptic } \\
\text { (temporarily) }\end{array}$ & & & \\
\hline Mobility & Functional & CAT & Ambusher & Small & Medium & High & & \\
\hline
\end{tabular}

1 


\section{Table 3 (on next page)}

Pearson correlation coefficients between continuous traits.

Statistically significant correlations without taking into account the Bonferroni correction are denoted in red color, while these incorporating the Bonferroni correction are indicated in green. Pairs of traits where non-linear regression indicated that a non-linear relationship was better than a linear one in describing trait fluctuations are framed (in all these cases the nonlinear $p<0.01$ remained significant after the Bonferroni correction). 


\begin{tabular}{|c|c|c|c|c|c|c|c|}
\hline Trait & In(Longevity) & $\begin{array}{r}\text { Age at } \\
\text { maturity }\end{array}$ & In(Fecundity) & $\begin{array}{r}\text { In(Maximum } \\
\text { length) }\end{array}$ & In(Depth) & $\begin{array}{r}\text { Trophic } \\
\text { level }\end{array}$ & $\begin{array}{r}\text { Optimal } \\
\text { temperature }\end{array}$ \\
\hline In(Longevity) & - & & & & & & \\
\hline $\begin{array}{l}\text { Age at } \\
\text { maturity }\end{array}$ & -0.34 & - & & & & & \\
\hline In(Fecundity) & 0.16 & -0.19 & - & & & & \\
\hline $\begin{array}{l}\text { In(Maximum } \\
\text { length) }\end{array}$ & 0.65 & -0.14 & 0.11 & - & & & \\
\hline In(Depth) & 0.22 & 0.08 & 0.01 & 0.30 & - & & \\
\hline Trophic level & 0.27 & 0.03 & -0.06 & 0.50 & 0.38 & - & \\
\hline $\begin{array}{l}\text { Optimal } \\
\text { temperature }\end{array}$ & -0.08 & -0.01 & 0.23 & 0.06 & -0.10 & -0.04 & . \\
\hline
\end{tabular}
2 


\section{Table 4 (on next page)}

Results of the statistical analyses between continuous and categorical traits.

Test (A: ANOVA, T: t-test, K: Kruskal-Wallis, M: Mann-Whitney) indicated as superscript next to result. $* p<0,05, * * p<0,01, * * p<<0,001$. Statistically significant differences between groups (categorical traits) without taking into account the Bonferroni correction are denoted in red color, while these incorporating the Bonferroni correction are indicated in green. 


\begin{tabular}{|c|c|c|c|c|c|c|c|}
\hline Trait & In(Longevity) & $\begin{array}{l}\text { Age-at- } \\
\text { maturity }\end{array}$ & In(Fecundity) & $\begin{array}{r}\text { In(Maximum } \\
\text { length) }\end{array}$ & In(Depth) & $\begin{array}{r}\text { Trophic } \\
\text { level } \\
\end{array}$ & $\begin{array}{r}\text { Optima } \\
\text { temperature }\end{array}$ \\
\hline Gonochorism & $-1.21^{\top}$ & $-339.50^{\mathrm{M}}$ & $391.5^{\mathrm{M}}$ & $-75.50^{\mathrm{M}}$ & $214.50^{\mathrm{M}}$ & $0.21^{\top}$ & $-1.23^{\top}$ \\
\hline Body shape & $* * 17.71^{\mathrm{K}}$ & $1.81^{\mathrm{A}}$ & $* * * 24.28^{\mathrm{K}}$ & $* * * 8.58^{\mathrm{A}}$ & $8.67^{\mathrm{K}}$ & $7.05^{\mathrm{K}}$ & $* * 4.04^{A}$ \\
\hline Habitat type & $0.79^{A}$ & $0.8^{\mathrm{A}}$ & $* * * 13.43^{K}$ & $* * * 9.38^{\mathrm{A}}$ & $0.13^{\mathrm{A}}$ & $* * 10.32^{\mathrm{A}}$ & ${ }^{*} 3.34^{A}$ \\
\hline $\begin{array}{l}\text { Seasonally } \\
\text { migratory }\end{array}$ & $629.50^{\mathrm{M}}$ & $-0.34^{\top}$ & ${ }^{*}-2.45^{\top}$ & ${ }^{* * *}-5.27^{\top}$ & $0.10^{\top}$ & $-1.61^{\top}$ & $-0.73^{\top}$ \\
\hline Distribution & $2.08^{A}$ & $* 2.75^{\mathrm{A}}$ & $1.52^{\mathrm{A}}$ & $2.00^{\mathrm{A}}$ & $* 3.42^{\mathrm{A}}$ & $0.83^{A}$ & $* * * 12.17^{A}$ \\
\hline $\begin{array}{l}\text { Seabed } \\
\text { morphology }\end{array}$ & $0.96^{A}$ & $0.48^{A}$ & $* * * 16.97^{\mathrm{K}}$ & $2.57^{\mathrm{A}}$ & $1.58^{\mathrm{A}}$ & $3.57^{\mathrm{A}}$ & ${ }^{*} 4.22^{A}$ \\
\hline Diet & $* * * 6.16^{\mathrm{A}}$ & $0.57^{\mathrm{A}}$ & $10.58^{\mathrm{K}}$ & $* * * 30.41^{\mathrm{A}}$ & $* * * 49.43^{K}$ & $* * * 143.7^{\mathrm{K}}$ & $1.65^{\mathrm{A}}$ \\
\hline $\begin{array}{l}\text { Feeding } \\
\text { behaviour }\end{array}$ & ${ }^{* * *} 27.29 \mathrm{~K}$ & $0.72^{\mathrm{A}}$ & $2.65^{\mathrm{A}}$ & ${ }^{* * *} 42.98^{\mathrm{K}}$ & ${ }^{* * *} 21.38^{\mathrm{K}}$ & ${ }^{* * *} 76.18^{A}$ & $1.64^{A}$ \\
\hline $\begin{array}{l}\text { Spawning } \\
\text { period }\end{array}$ & $4.65^{\mathrm{K}}$ & $0.83^{A}$ & $0.65^{\mathrm{A}}$ & $1.13^{\mathrm{A}}$ & $* 3.00^{\mathrm{A}}$ & $0.86^{A}$ & ${ }^{*} 2.49^{A}$ \\
\hline $\begin{array}{l}\text { Spawning } \\
\text { habitat }\end{array}$ & $* * 1276.50^{\mathrm{M}}$ & $1.03^{\top}$ & $* *-2.85^{\top}$ & $* * * 1664^{M}$ & $* * * 1762^{\mathrm{M}}$ & $-1.53^{\top}$ & $-0.8^{\top}$ \\
\hline Depth range & $0.11^{\top}$ & $* *-1222^{\mathrm{M}}$ & $-1.18^{\top}$ & ${ }^{*} 2.5^{\top}$ & ${ }^{* * *}-63.65^{\mathrm{M}}$ & $* * * 3.53^{\top}$ & $-0.76^{\top}$ \\
\hline $\begin{array}{l}\text { Temperature } \\
\text { range }\end{array}$ & $1.59^{\top}$ & $-0.49^{\top}$ & $-1.83^{\top}$ & $-0.95^{\top}$ & $0.03^{\top}$ & $681.5^{\mathrm{M}}$ & $* * *-4.8^{\top}$ \\
\hline Salinity range & $0.81^{\top}$ & $-1.3^{\top}$ & $1.37^{\top}$ & $1.51^{\top}$ & $* * *-5.47^{\top}$ & $-1.58^{\top}$ & -0.31 \\
\hline Sociability & $0.23^{A}$ & $1.98^{\mathrm{A}}$ & $* * 12.72^{\mathrm{K}}$ & $0.18^{A}$ & $2.24^{\mathrm{A}}$ & $7.6^{\mathrm{K}}$ & $2.16^{A}$ \\
\hline Exposure & $0.11^{\mathrm{A}}$ & *3.78A & $2.22^{\mathrm{A}}$ & $0.81^{\mathrm{A}}$ & $* 4.25^{\mathrm{A}}$ & $0.89^{A}$ & ${ }^{*} 3.02^{A}$ \\
\hline Mobility & ${ }^{*} 4.31^{\mathrm{A}}$ & $0.82^{\mathrm{A}}$ & ${ }^{* *} 4.23^{\mathrm{A}}$ & ${ }^{* *} 4.44^{\mathrm{A}}$ & $* 3.48 \mathrm{~A}$ & $* * 15.25^{\mathrm{K}}$ & ${ }^{* *} 4.79^{A}$ \\
\hline
\end{tabular}

2 


\section{Table 5 (on next page)}

Summary of the main findings of the significant relationships between continuous and categorical traits.

For pairwise contrasts between trait categories see Supplementary Figure S1. 


\begin{tabular}{|c|c|c|}
\hline $\begin{array}{l}\text { Continuous } \\
\text { trait }\end{array}$ & Categorical trait & Main findings \\
\hline \multirow[t]{4}{*}{ Longevity } & Body shape & Highest in flat species, lowest in rounded species \\
\hline & Feeding type & Highest in ambushing \& active predators, lowest in grazers \\
\hline & Spawning habitat & Higher in pelagic spawners \\
\hline & Diet & Highest in piscivorous species, lowest in zooplanktivorous-zoobentivorous \\
\hline \multirow[t]{3}{*}{ Fecundity } & Body shape & Higher in atractoid and deep-bodied, lower in flat and long species \\
\hline & Habitat type & Highest in pelagic species, intermediate in benthopelagic, lowest in benthic \\
\hline & Seabed type & Highest in the open sea and over hard substrate, lowest over soft substrate \\
\hline \multirow{6}{*}{$\begin{array}{l}\text { Maximum } \\
\text { length }\end{array}$} & Body shape & Higher in long, atractoid and flat body shape, lowest in rounded body shape \\
\hline & $\begin{array}{l}\text { Habitat type } \\
\text { Seasonal }\end{array}$ & Highest in pelagic species, intermediate in benthic, lowest in benthopelagic \\
\hline & migrations & Higher in non-migratory species \\
\hline & Diet & Highest in piscivorous species \\
\hline & Feeding type & Highest in active \& ambushing predators, lowest in grazers \\
\hline & Spawning habitat & Higher in pelagic spawners \\
\hline \multirow[t]{5}{*}{ Depth } & Depth range & Eurybathic species deeper \\
\hline & Diet & Herbivores most shallow, piscivores and zoobenthivores deeper \\
\hline & Feeding type & Active predators deepest, grazers shallowest \\
\hline & Spawning habitat & Benthic spawners deeper \\
\hline & Salinity range & Euryhaline species in shallower depth \\
\hline \multirow{5}{*}{$\begin{array}{l}\text { Trophic } \\
\text { level }\end{array}$} & Diet & Herbivores have lowest trophic level, piscivores the highest \\
\hline & Feeding type & Highest in ambushing predators, lowest in grazers \\
\hline & Habitat type & Highest in pelagic species \\
\hline & Depth range & Eurybathic species have higher trophic level \\
\hline & Mobility & Ambushers have highest trophic level \\
\hline \multirow{3}{*}{$\begin{array}{l}\text { Optimal } \\
\text { temperature }\end{array}$} & Mobility & Higher in species of high \& medium mobility, lower in small mobility species \\
\hline & $\begin{array}{l}\text { Temperature } \\
\text { range }\end{array}$ & Higher in stenothermal species \\
\hline & Distribution & Highest in tropical species, lowest in temperate \\
\hline
\end{tabular}


Figure 1

A. Distribution of continuous traits of the nekton species examined. B. Ranges and/or means of range-type traits. Species are ranked according to the mean of the range.

Note: In the bibliography, sometimes fecundity is provided as the maximum number of offspring with no indication of the minimum. In these cases it is here denoted not as a range, but with the same symbol as the mean.
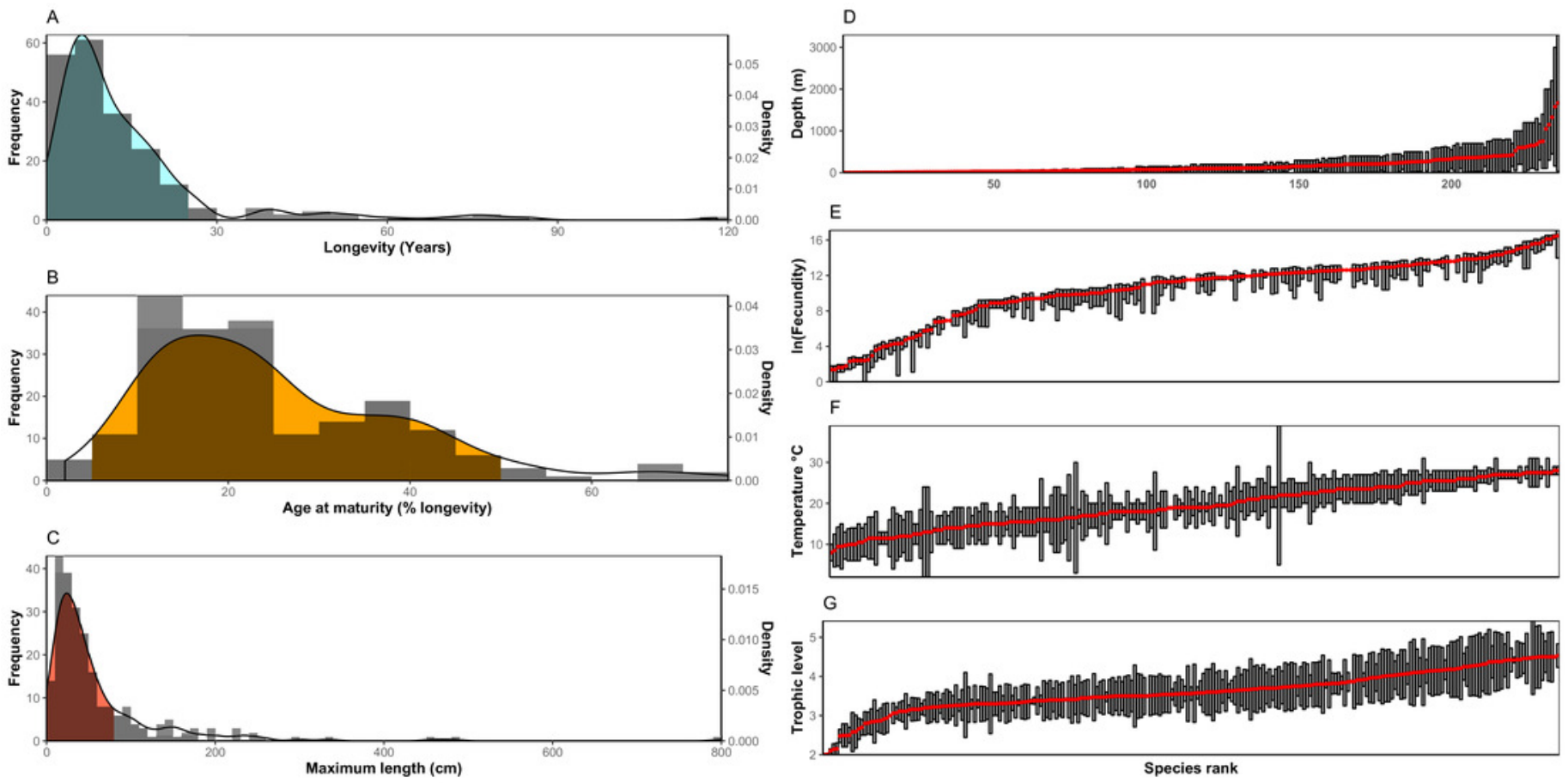
Figure 2

Frequency distribution of categorical traits of the nektonic species examined
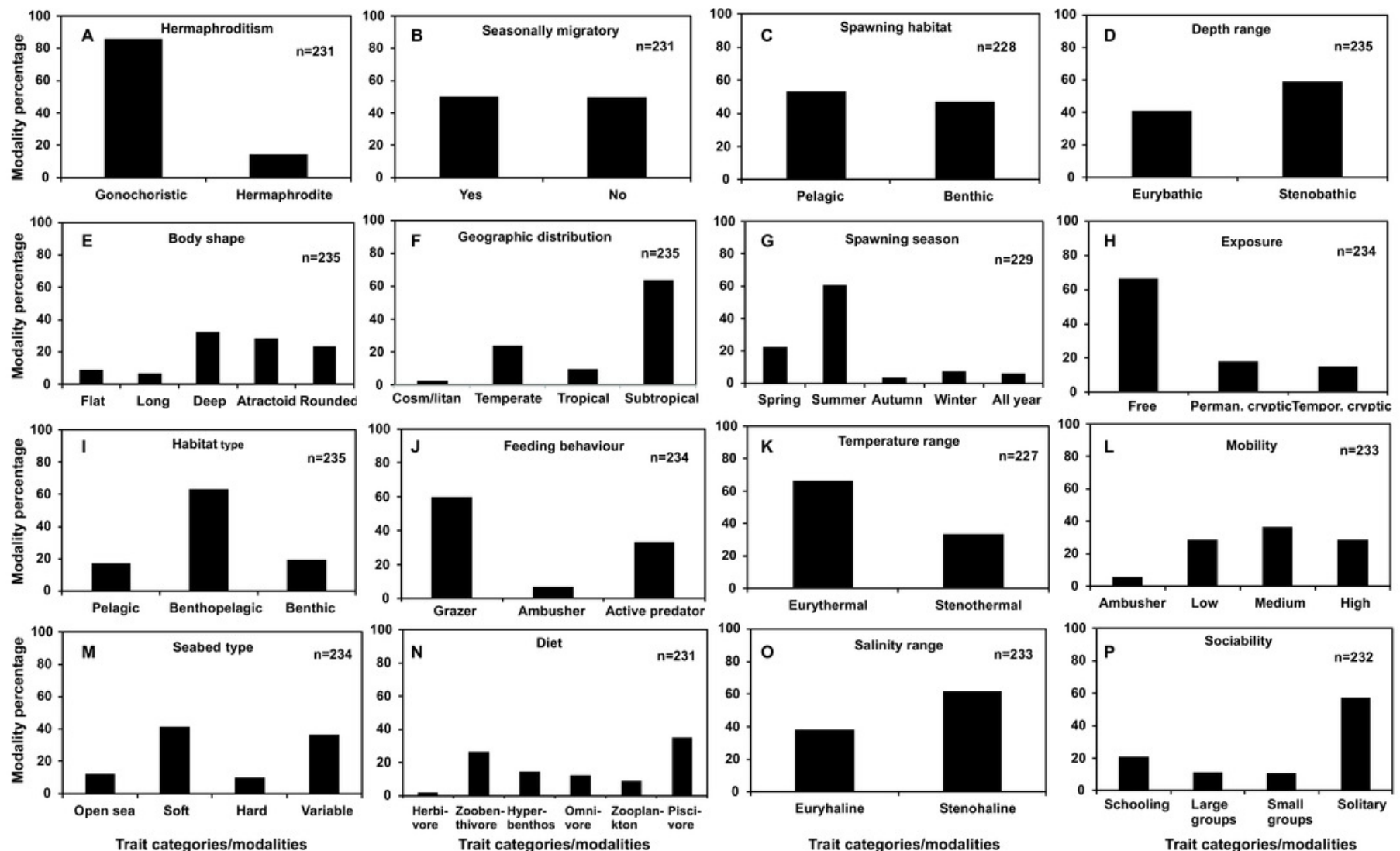
Figure 3

The statistically significant correlations or non-linear relationships between continuous traits after incorporating the Bonferroni correction. 

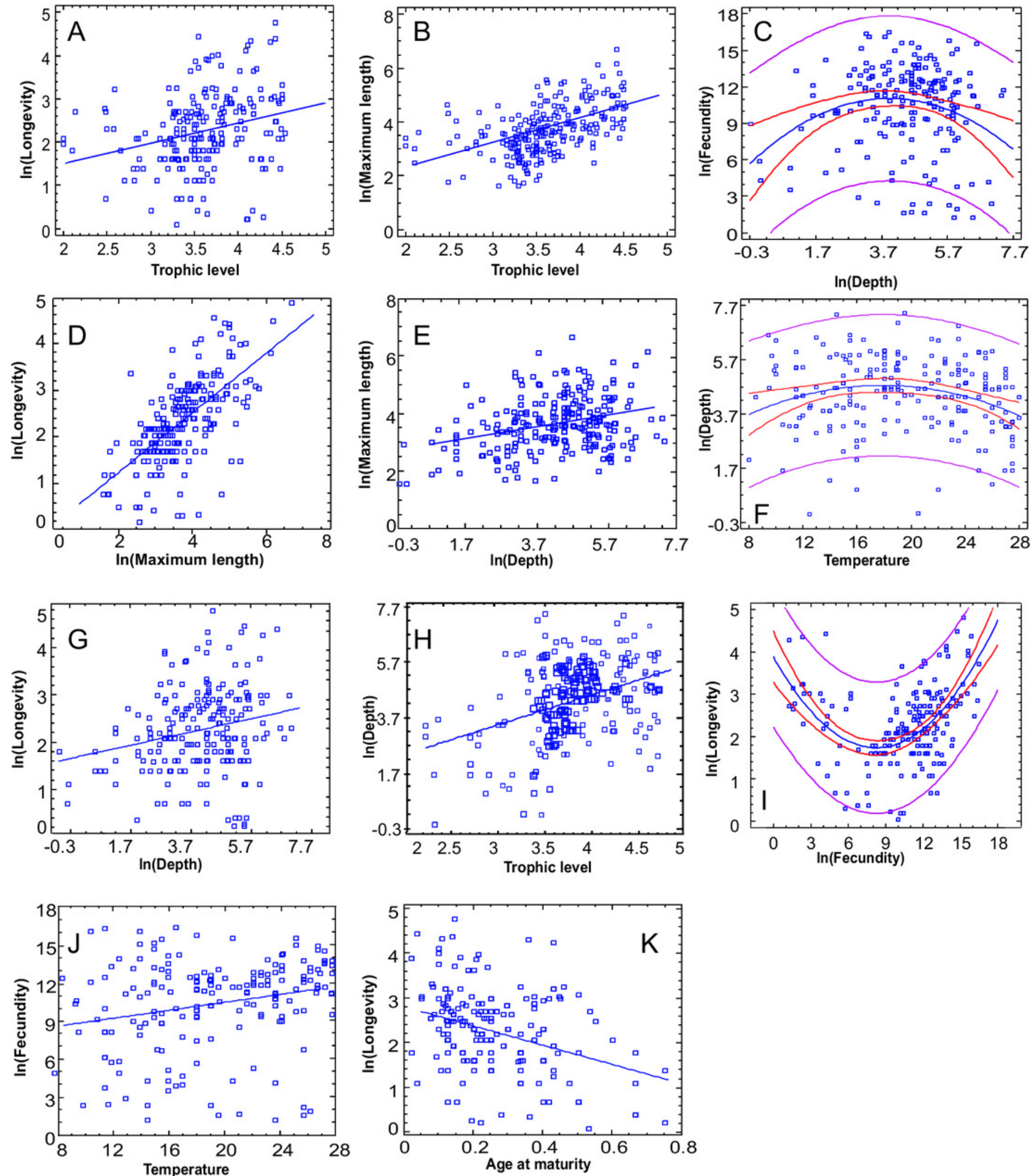
Figure 4

Diagonal matrix of positive, random, and negative co-occurrence between the trait category/modality pairs. Cumulative number of positive, negative and random cooccurrences are also provided for each trait category. 


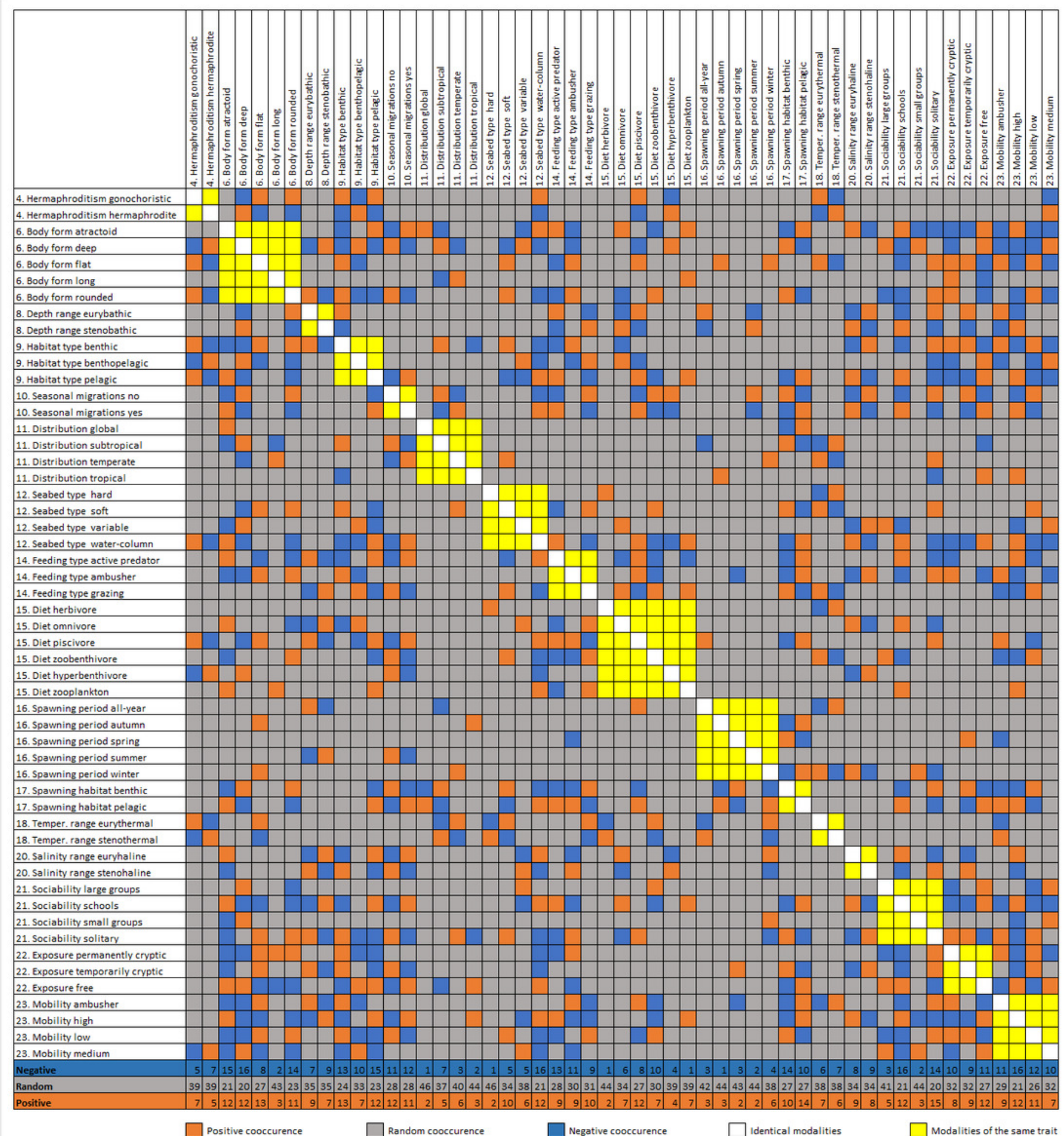


Figure 5

Species positions across the first two major axes (explaining 19\% of cumulative variance) of the Hill-Smith ordination. Species major groups (at $42 \%$ dissimilarity) are indicated by colours corresponding to the dendrogram of Figure 6 and some species names

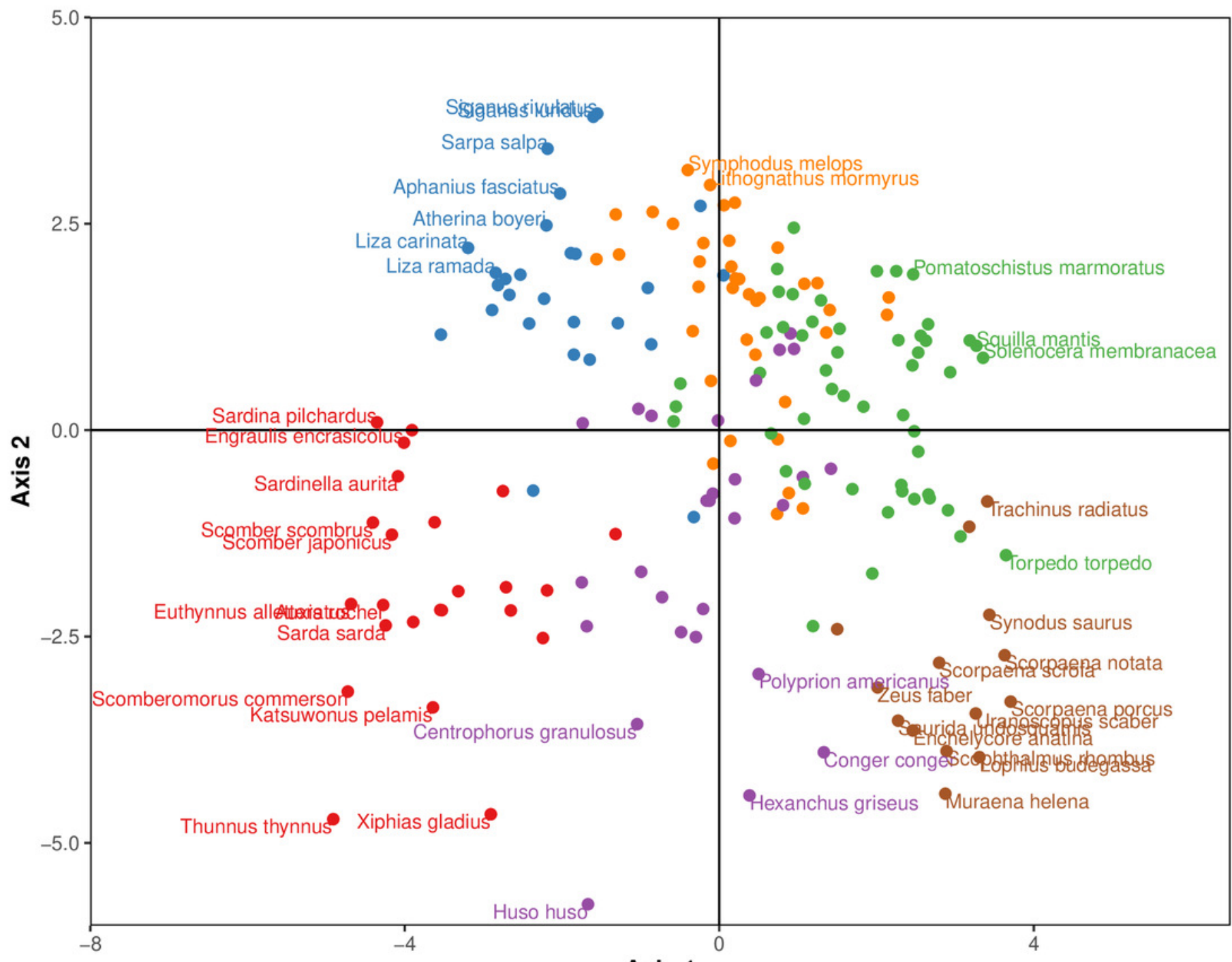

Axis 1 
Figure 6

Hierarchical clustering of nektonic species using the coordinates of the 11 major axes of the Hill-Smith ordination and functional group identification at two dissimilarity levels: 42\% (Groups A-F) and 13\% (Groups 1-18).

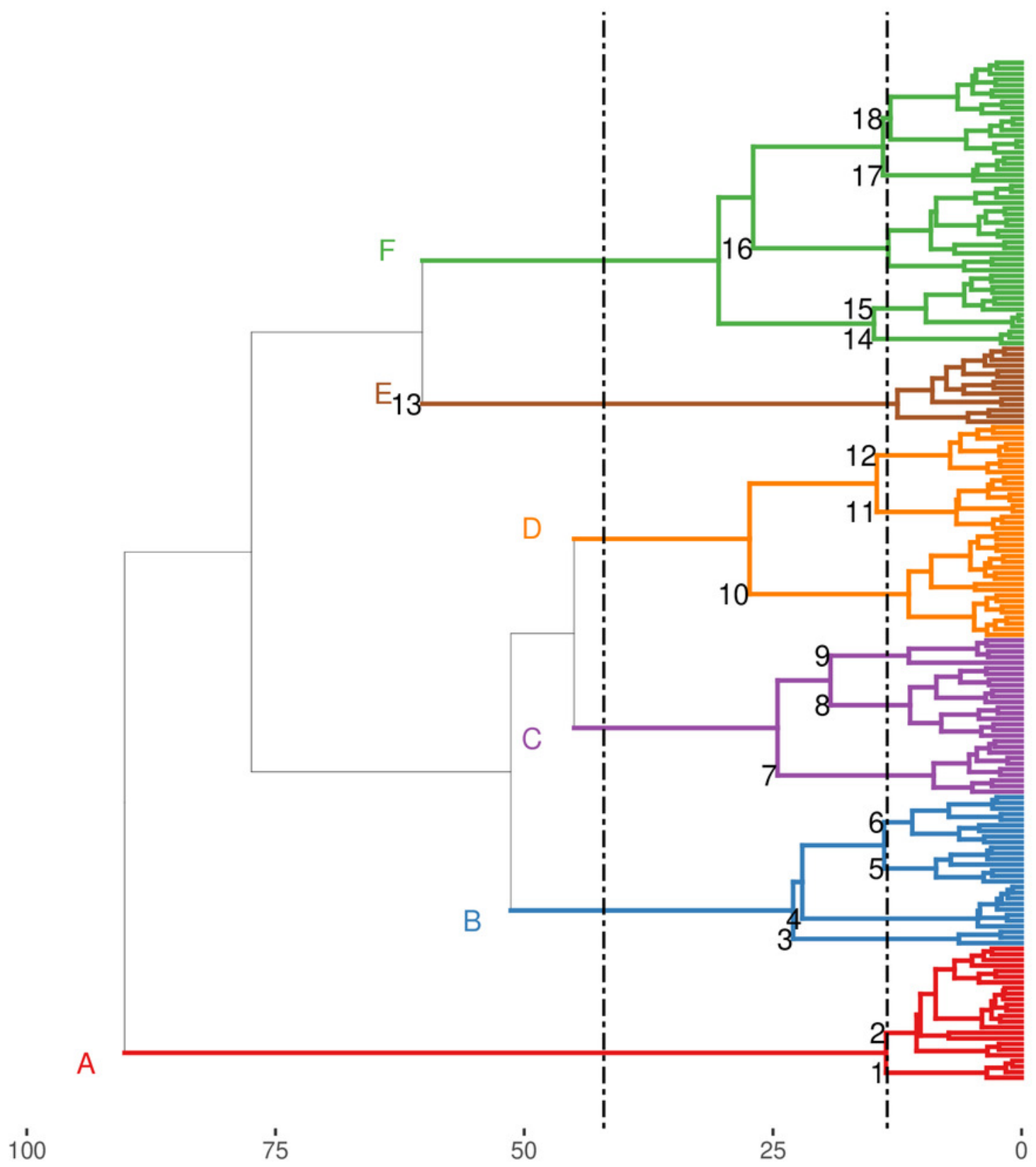

